\title{
Understanding high wintertime ozone pollution events in an oil- and natural gas-producing region of the western US
}

\author{
R. Ahmadov ${ }^{1,2}$, S. McKeen ${ }^{1,2}$, M. Trainer ${ }^{2}$, R. Banta ${ }^{2}$, A. Brewer ${ }^{2}$, S. Brown ${ }^{2}$, P. M. Edwards ${ }^{1,2, *}$, J. A. de Gouw ${ }^{1,2}$, \\ G. J. Frost ${ }^{1,2}$, J. Gilman ${ }^{1,2}$, D. Helmig ${ }^{3}$, B. Johnson ${ }^{2}$, A. Karion ${ }^{1,2}$, A. Koss ${ }^{1,2}$, A. Langford ${ }^{2}$, B. Lerner ${ }^{1,2}$, J. Olson ${ }^{1,2}$, \\ S. Oltmans ${ }^{1,2}$, J. Peischl ${ }^{1,2}$, G. Pétron ${ }^{1,2}$, Y. Pichugina ${ }^{1,2}$, J. M. Roberts ${ }^{2}$, T. Ryerson ${ }^{2}$, R. Schnell ${ }^{2}$, C. Senff ${ }^{1,2}$, \\ C. Sweeney ${ }^{1,2}$, C. Thompson ${ }^{3}$, P. R. Veres ${ }^{1,2}$, C. Warneke ${ }^{1,2}$, R. Wild ${ }^{1,2}$, E. J. Williams ${ }^{2}$, B. Yuan ${ }^{1,2}$, and R. Zamora ${ }^{2}$ \\ ${ }^{1}$ Cooperative Institute for Research in Environmental Sciences, University of Colorado at Boulder, Boulder, CO, USA \\ ${ }^{2}$ Earth System Research Laboratory, National Oceanic and Atmospheric Administration, Boulder, CO, USA \\ ${ }^{3}$ Institute for Arctic and Alpine Research, University of Colorado at Boulder, Boulder, CO, USA \\ *now at: Department of Chemistry, University of York, York, UK
}

Correspondence to: R. Ahmadov (ravan.ahmadov@ noaa.gov)

Received: 15 July 2014 - Published in Atmos. Chem. Phys. Discuss.: 8 August 2014

Revised: 14 November 2014 - Accepted: 14 November 2014 - Published: 14 January 2015

\begin{abstract}
Recent increases in oil and natural gas (NG) production throughout the western US have come with scientific and public interest in emission rates, air quality and climate impacts related to this industry. This study uses a regionalscale air quality model (WRF-Chem) to simulate high ozone $\left(\mathrm{O}_{3}\right)$ episodes during the winter of 2013 over the Uinta Basin (UB) in northeastern Utah, which is densely populated by thousands of oil and NG wells. The high-resolution meteorological simulations are able qualitatively to reproduce the wintertime cold pool conditions that occurred in 2013, allowing the model to reproduce the observed multi-day buildup of atmospheric pollutants and the accompanying rapid photochemical ozone formation in the UB.

Two different emission scenarios for the oil and NG sector were employed in this study. The first emission scenario (bottom-up) was based on the US Environmental Protection Agency (EPA) National Emission Inventory (NEI) (2011, version 1) for the oil and NG sector for the UB. The second emission scenario (top-down) was based on estimates of methane $\left(\mathrm{CH}_{4}\right)$ emissions derived from in situ aircraft measurements and a regression analysis for multiple species relative to $\mathrm{CH}_{4}$ concentration measurements in the UB. Evaluation of the model results shows greater underestimates of $\mathrm{CH}_{4}$ and other volatile organic compounds (VOCs) in the simulation with the NEI-2011 inventory than in the case when the top-down emission scenario was used. Unlike VOCs, the NEI-2011 inventory significantly overesti-
\end{abstract}

mates the emissions of nitrogen oxides $\left(\mathrm{NO}_{\mathrm{x}}\right)$, while the topdown emission scenario results in a moderate negative bias. The model simulation using the top-down emission case captures the buildup and afternoon peaks observed during high $\mathrm{O}_{3}$ episodes. In contrast, the simulation using the bottomup inventory is not able to reproduce any of the observed high $\mathrm{O}_{3}$ concentrations in the UB. Simple emission reduction scenarios show that $\mathrm{O}_{3}$ production is VOC sensitive and $\mathrm{NO}_{\mathrm{x}}$ insensitive within the UB. The model results show a disproportionate contribution of aromatic VOCs to $\mathrm{O}_{3}$ formation relative to all other VOC emissions. The model analysis reveals that the major factors driving high wintertime $\mathrm{O}_{3}$ in the UB are shallow boundary layers with light winds, high emissions of VOCs from oil and NG operations compared to $\mathrm{NO}_{\mathrm{x}}$ emissions, enhancement of photolysis fluxes and reduction of $\mathrm{O}_{3}$ loss from deposition due to snow cover.

\section{Introduction}

The development of new drilling and stimulation technologies has resulted in a large increase in the number of active unconventional oil and NG wells and accelerated oil and NG production onshore in the US during the last decade (www. eia.gov). The quantification of the potential impacts of oil and NG production emissions on climate and air quality is a topic that has received recent attention (Schnell et al., 2009; 
Alvarez et al., 2012; Carlton et al., 2014). Several studies based on atmospheric measurements suggest that the leakage rate of $\mathrm{CH}_{4}$ from the $\mathrm{NG}$ production, transmission, storage and distribution systems in North America may be significantly higher than is estimated within the regulatory emission inventories (Pétron et al., 2012; Karion et al., 2013; Miller et al., 2013; Brandt et al., 2014). At the same time, increased production of NG in the US stimulates switching from coal to NG by the power plants for electricity generation, which has led to a reduction in emissions of carbon dioxide and other pollutants by power plants in the US (de Gouw et al., 2014).

The oil and NG exploration, production, and processing systems also contribute significant amounts of non-methane hydrocarbons to the atmosphere. Katzenstein et al. (2003) reported elevated alkane concentrations in air samples collected at the surface in the southwestern US and attributed them to the oil and NG operations in the region. The authors also measured alkyl nitrate species, indicating enhanced photochemistry in the presence of VOC emissions and $\mathrm{NO}_{\mathrm{x}}$. Pétron et al. (2012) analyzed daily air samples collected at the National Oceanic and Atmospheric Administration (NOAA) Boulder Atmospheric Observatory located in northeastern Colorado, and found highly correlated light alkane enhancements in a regionally distributed mix of sources in the Denver-Julesburg Basin. Additionally, $\mathrm{CH}_{4}$ and VOC data from a 2008 summer pilot study involving mobile-based surveys found that leaks of raw NG and flashing emissions from condensate storage tanks can explain the alkane ratios that were observed in air masses impacted by oil and NG operations. Pétron et al. (2012) suggested that the emissions of the measured species are most likely underestimated in existing emission inventories, which was supported by a recent study (Pétron et al., 2014). Gilman et al. (2013) analyzed extensive VOC measurements at the same site in Colorado during the winter of 2011, confirming an abundance of alkanes associated with the oil and NG production operations in northeastern Colorado based on differences in chemical signatures (e.g., i-pentane/n-pentane ratios and relative amounts of acetylene to propane) between urban sources and oil/gas well emissions. There have also been studies to estimate the emissions of pollutants in the eastern US from NG production, processing, transmission and distribution (Jackson et al., 2014; Roy et al., 2014).

Ozone is a major surface air pollutant that adversely affects human health and vegetation (Jerrett et al., 2009; Anenberg et al., 2010). The US National Ambient Air Quality Standard (NAAQS) for $8 \mathrm{~h}$ average $\mathrm{O}_{3}$ mixing ratios set by the EPA is 75 parts per billion (ppb) (www.epa.gov/ air/criteria.html). Traditionally, high $\mathrm{O}_{3}$ and photochemical smog have been associated with hot and sunny weather conditions over urban areas with high vehicle, residential and industrial emissions (Lelieveld and Dentener, 2000; Trainer et al., 2000; Ryerson et al., 2003; Banta et al., 2011). Consequently, ground-level elevated $\mathrm{O}_{3}$ was considered to be primarily a summertime problem in urban and suburban areas. Contrary to the traditional view, in the rural Upper Green River basin (UGRB), Wyoming, in the winters of 2005 and 2008, high levels of $\mathrm{O}_{3}$ were measured, with hourly levels exceeding $140 \mathrm{ppb}$ in 2008 (Schnell et al., 2009). Very high $\mathrm{O}_{3}$ mixing ratios, with hourly values reaching as high as $166 \mathrm{ppb}$, were observed in the same region during the winter of 2011, well above estimated surface background levels of $40 \mathrm{ppb}$ (Rappenglück et al., 2014). As of July 2012, EPA declared the UGRB a non-attainment area for the 2008 ground-level $8 \mathrm{~h}$ ozone standard (Rappenglück et al., 2014).

Similar phenomena were observed in the UB, Utah, which has experienced rapid development of the oil and NG industry over the last several years (Oltmans et al., 2014a). The high $\mathrm{O}_{3}$ episodes in both the UGRB and UB are associated with oil and NG production and processing, below freezing temperatures, and when persistent snow cover is present under prevailing light wind conditions and associated clear skies. This combination produces strong, shallow temperature inversions that trap fossil fuel effluents in a stable boundary layer. Sunlight passing through the trapped pollutants and reflecting back off the high-albedo snow drives diurnal photochemical production of $\mathrm{O}_{3}$ that peaks soon after solar noon (Schnell et al., 2009; Rappenglück et al., 2014). In the absence of the above meteorological conditions, $\mathrm{O}_{3}$ mixing ratios were near the background levels, in the $40-50 \mathrm{ppb}$ range in the UGRB and UB (Oltmans et al., 2014a).

It should be noted that the impact of the oil and NG production on ambient air quality goes beyond the wintertime. Kemball-Cook et al. (2010) modeled the impact of the Haynesville Shale development on ambient $\mathrm{O}_{3}$ levels in Texas and Louisiana. Their photochemical modeling of the year 2012 showed increases in $8 \mathrm{~h}$ average ozone values of up to $5 \mathrm{ppb}$ within northeastern Texas and northwestern Louisiana resulting from development in the Haynesville Shale. A model study by Rodriguez et al. (2009) found that the rise in oil and NG production in the Intermountain West could increase maximum $8 \mathrm{~h}$ average $\mathrm{O}_{3}$ levels by $9.6 \mathrm{ppb}$ in southwestern Colorado and northwestern New Mexico in summer. Cooper et al. (2012) analyzed long-term surface $\mathrm{O}_{3}$ measurements at rural sites from 1990 to 2010 across the US, observing that eastern US sites exhibited a decrease in summertime $\mathrm{O}_{3}$ over that period, while the western sites did not show a decrease in summertime $\mathrm{O}_{3}$. These studies demonstrate the importance of future research needed to quantify accurately the role of rising oil and NG emissions as they relate to ambient $\mathrm{O}_{3}$ levels in the western US.

Researchers from NOAA and other partnering organizations conducted intensive measurement campaigns in the UB (Fig. 1) during the winters of 2012, 2013 and 2014. The full review of the Uinta Basin Winter Ozone Study (UBWOS) field study in 2013 can be found in the report available at http://www.deq.utah.gov/locations/U/uintahbasin/studies/ UBOS-2013.htm. The topography of the UB is shown in Fig. 1. Here, we focus on measurements from the 2012 and 


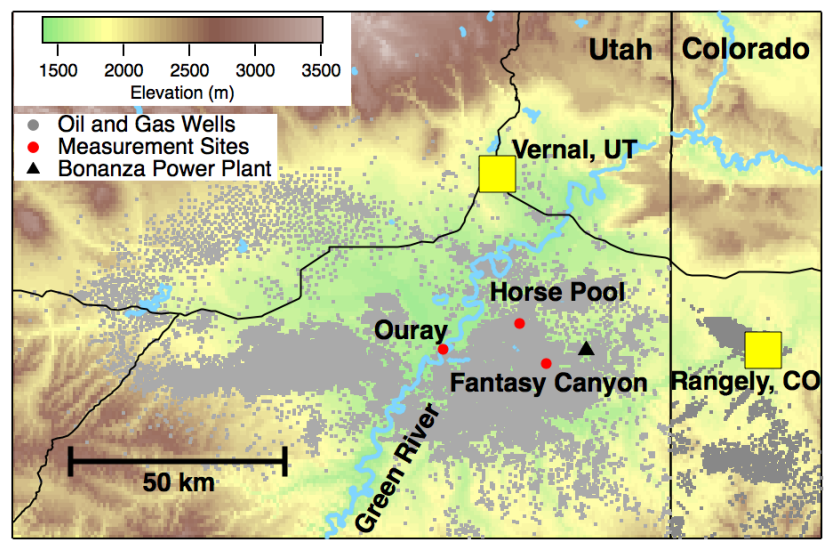

Figure 1. Topography of the Uinta Basin, UT. The locations of oil and NG wells, measurement sites - Ouray $\left(40.1348^{\circ} \mathrm{N}\right.$, $\left.109.6446^{\circ} \mathrm{W}\right)$, Horse Pool $\left(40.1431^{\circ} \mathrm{N}, 109.4674^{\circ} \mathrm{W}\right)$ and Fantasy Canyon $\left(40.0582^{\circ} \mathrm{N}, 109.3941^{\circ} \mathrm{W}\right)$ during the UBWOS-2013 field campaign, and Bonanza Power Plant $\left(40.0864^{\circ} \mathrm{N}, 109.2844^{\circ} \mathrm{W}\right)-$ and towns (Vernal, UT and Rangely, $\mathrm{CO}$ ) are also shown.

2013 field campaigns only, with wintertime meteorological and chemical conditions sharply different between the 2 years. During January and February 2012, the UB experienced relatively warm weather (above freezing temperatures during daytime), and the ground was mostly snow free. Thus, the meteorological conditions, including wind speed and mixing layer heights, were not favorable for $\mathrm{O}_{3}$ production. In contrast, during the winter of 2013, the ground was covered by a layer of snow $(\sim 20-30 \mathrm{~cm})$, and air temperatures were typically $10-15^{\circ} \mathrm{C}$ lower than in 2012 , with high $\mathrm{O}_{3}$ episodes experienced frequently. Helmig et al. (2014) analyzed observations of VOCs from both the UBWOS 2012 and 2013 field campaigns, showing that the 2013 concentrations of air pollutants such as benzene and toluene were a factor of 5 to 10 times higher than reported values over major US cities.

During UBWOS-2013, the UB was mostly under the influence of synoptic-scale surface high-pressure systems. These conditions resulted in frequent stagnation events in the UB, with light wind and shallow boundary layers. The stagnation episodes were interrupted by occasional storms passing over the UB. The snow cover prevented the heat exchange of air with the ground. Consequently, the boundary layers were shallow $(\sim 50-200 \mathrm{~m})$ during daytime. Thus, persistent stagnant meteorological conditions were present throughout most of the 2013 study period in the UB. During the UBWOS field campaigns, a large variety of meteorological, chemistry, and flux measurements were conducted at the Horse Pool ground site (Fig. 1). In addition, frequent tethersonde balloon launchings took place at three sites during the winter of 2013 , producing high-resolution vertical profiles of $\mathrm{O}_{3}$, temperature, and humidity (Oltmans et al., 2014b). These sites include the Horse Pool, Ouray and Fantasy Canyon locations shown in Fig. 1.

The high wintertime $\mathrm{O}_{3}$ observations have motivated researchers to attempt to model the photochemical processes driving the $\mathrm{O}_{3}$ production resulting from the oil and NG production-related emissions. Carter and Seinfeld (2012) used a detailed chemical mechanism in a box model to study high $\mathrm{O}_{3}$ production observed at two sites in the UGRB in 2008 and 2011. The authors performed multiple sensitivity analyses to assess the effects of ambient VOC speciation, air temperature and atmospheric radiation conditions on the $\mathrm{O}_{3}$ production. The study found that one site for the 2008 episode was highly $\mathrm{NO}_{\mathrm{x}}$ sensitive and insensitive to VOCs and nitrous acid $\left(\mathrm{HNO}_{2}\right)$, while the other 2008 case and both 2011 cases were highly sensitive to changes in specified VOC and $\mathrm{HNO}_{2}$ concentrations. The authors stressed the need for full three-dimensional (3-D) air quality models to address the high $\mathrm{O}_{3}$ episodes in the UGRB and similar regions due to regional variability in photochemical and meteorological conditions.

Edwards et al. (2013) conducted a box modeling study of $\mathrm{O}_{3}$ production in the UB in winter 2012 using a near-explicit gas chemistry scheme - Master Chemical Mechanism v3.2 for data collected at the Horse Pool site during the UBWOS2012 field campaign. According to their box model study, the photochemical regime during that period was characterized as radical limited. Edwards et al. (2014) used a similar chemical box model for the conditions observed in the winter of 2013 in the UB. The study concluded the importance of the build-up and photolysis of carbonyls in deriving high $\mathrm{O}_{3}$ in the UB during the winter of 2013.

The stagnant meteorological conditions during the winter of 2013 in the UB are characterized as a "cold pool". Cold-pool-type inversion layers, occurring within basins and valleys in the western US, have been studied extensively (Banta and Cotton, 1981; Clements et al., 2003; Lareau et al., 2013). Such valley cold pools (VCP) are identified when a radiosonde indicates the presence of an inversion below the maximum crest height of the surrounding mountains, and average wind speeds beneath the inversion top that are less than $5 \mathrm{~m} \mathrm{~s}^{-1}$ (Reeves and Stensrud, 2009). The VCPs form as an upper-level ridge approaches the western US and in response to strong mid-level warming, and they can exist several days until being removed, usually by advection or turbulent erosion processes (Reeves and Stensrud, 2009). These "cold pool"-like conditions can result in high air pollution episodes during wintertime. It has been known that meteorological models traditionally have difficulties in accurately simulating such meteorological conditions (Zhong et al., 2001; Baker et al., 2011). Neeman et al. (2014) simulated cold pool situations in the UB during the winter of 2013 and examined the sensitivity of the boundary layer structure to the treatment of the cloud microphysics and snow cover in their meteorological model settings. 
Table 1. List of acronyms used in the text.

\begin{tabular}{ll}
\hline Acronym & Description \\
\hline 3-D & Three-dimensional \\
AGL & Above ground level \\
CB & Carbon bond \\
DU & Dobson unit \\
EPA & Environmental Protection Agency \\
IR & Impact ratio \\
MB & Median bias \\
MMO & Median of model over observation \\
MO & Median of observations \\
MST & Mountain Standard Time \\
NAAQS & National Ambient Air Quality Standards \\
NEI & National Emissions Inventory \\
NG & Natural gas \\
NOAA & National Oceanic and Atmospheric \\
& Administration \\
PBL & Planetary boundary layer \\
ppb & Parts per billion \\
RACM & Regional Atmospheric Chemistry \\
TUV & Mechanism \\
UB & Tropospheric Ultraviolet and Visible \\
UBWOS & Uinta Basin \\
UGRB & Uinta Basin Winter Ozone Study \\
VCPs & Upper Green River basin \\
VOCs & Valley cold pools \\
WRF-Chem & Welatile organic compounds Research and Forecasting \\
& with Chemistry \\
\hline
\end{tabular}

These studies, and the challenges related to the modeling of wintertime $\mathrm{O}_{3}$, are a motivation for investigating the wintertime $\mathrm{O}_{3}$ problem by means of a coupled 3-D meteorologychemistry atmospheric model. Such models treat meteorology, anthropogenic emissions, advection and vertical mixing of chemical species, photochemical and removal processes in a unified modeling framework. Here, we present results from the Weather Research and Forecasting with Chemistry (WRF-Chem) meteorology-chemistry model, focusing on simulations for the winter of 2013, but also presenting results for 2012 using identical emission scenarios for both years in the comparisons.

Results are presented using two emission data sets for the oil and NG operations located in the UB. One set of emissions is based on an anthropogenic emission inventory used for regulatory purposes, and the other set is derived from in situ atmospheric measurements of reactive odd nitrogen $\left(\mathrm{NO}_{\mathrm{y}}\right)$, VOCs and $\mathrm{CH}_{4}$. We present evaluations of model simulations using observations from the fully instrumented ground site as well as tethersonde profiles from three locations within the UB (Fig. 1). The paper focuses primarily on ozone-related photochemistry within the simulations, but important meteorological features are discussed as well. A sensitivity analysis is also presented that illustrates the im- portance of various physical and chemical processes to elevated wintertime $\mathrm{O}_{3}$ formation in the UB. Table 1 lists all the acronyms used in this paper.

\section{Emission data sets used in the model}

Two emission data sets are used in this study: a bottom-up inventory based on information provided by the US EPA, and a top-down emission scenario for the oil/gas sector (emissions related to oil and $\mathrm{NG}$ operations) derived from $\mathrm{CH}_{4}$ and a suite of VOC and $\mathrm{NO}_{\mathrm{y}}$ observations at the Horse Pool site during the UBWOS 2012 and 2013 field campaigns. Four major source categories are treated in each emission case: point, mobile onroad, mobile nonroad, and area (or nonpoint). The mobile sector emissions are identical in both cases, and are based on the US EPA NEI-2005, as described in other regional modeling studies, e.g., Kim et al. (2011), Ahmadov et al. (2012), and Brioude et al. (2013). Point source emission estimates within the top-down scenario are also based on the NEI-2005, while the bottom-up point source emission estimates are specified according to the NEI-2011 national inventory. Since the NEI-2005 inventory does not include any oil/gas sector emissions for the UB, double counting of emissions in the top-down emission data set is avoided by using NEI-2005 for non-oil/gas sector emission estimates.

The coal-fired Bonanza Power Plant (Fig. 1) located in the southeastern part of the UB is the predominant point source of $\mathrm{NO}_{\mathrm{x}}$ and sulfur dioxide $\left(\mathrm{SO}_{2}\right)$ in the UB. Measurements during the winter 2013 study showed that when shallow boundary layers were present, the power plant effluents were injected above the boundary layer into the free atmosphere. For the UB domain used here, $\mathrm{CH}_{4}$ and VOC emissions are dominated by the oil and gas production sector within the area (or nonpoint) source category. Details of the emission processing for this sector and for the two emission data sets are presented below. Due to the geographical location of the UB (Fig. 1) and the locations of the emission sources in the vicinity, the upwind transport of air pollution to the UB is small. The major pollution source outside of the basin is Salt Lake City, which is located more than $100 \mathrm{~km}$ away. It should be noted that the UB is sparsely populated; thus, the urban emissions are low.

\subsection{EPA NEI-2011 oil/gas sector emissions (bottom-up)}

The bottom-up emission inventory for the UB oil/gas sources is based on the US EPA NEI-2011 (version 1) national inventory released in August 2013 (US EPA, 2013, available at $\mathrm{ftp} / / / \mathrm{ftp}$. epa.gov/EmisInventory/2011v6/flat_files). The national inventory contains annual emission estimates of total VOCs from the oil/gas sector at a county level for nonpoint sources, or at specific locations for point sources. Ancillary information for temporal partitioning, VOC speciation, 
and spatial distribution of nonpoint sources is available through data files in the version 1 modeling platform (ftp://ftp.epa.gov/EmisInventory/2011v6/v1platform, release date 11/8/2013). The EPA SPECIATE 4.3 database (e.g., Simon et al., 2010) is used for default VOC profile species assignments and the VOC to total organic gases (including $\mathrm{CH}_{4}$ ) emission conversions. Within the modeling platform, the oil/gas sector VOC speciation for nine distinct oil- and natural gas-producing basins are specified according to Western Regional Air Partnership recommendations (http: //www.wrapair.org/forums/ogwg/PhaseIII_Inventory.html).

Four distinct VOC speciation profiles are provided for the UB, and mapped with EPA assignments (gsref_cmaq_cb05_soa_2011ec_v6_11f_onroad_06sep2013 .txt) to the source classification code or activity that is provided with the state-supplied VOC emission estimates. VOC profile to VOC species assignments are available for the Carbon Bond version 5 (CB-05) chemical mechanism within the file gspro_cmaq_cb05_soa_2011ec_v6_11f_beis_nf.txt. CB-05 VOC speciation assignments to the Regional Atmospheric Chemistry Mechanism (RACM) (Stockwell et al., 1997) are straightforward for non-alkane species (mostly formaldehyde, toluene, xylenes and ethylene). The weight fraction of "PAR", representing the lumped alkane class within CB-05, was partitioned into the RACM alkane classes according to the alkane partitioning observed at the Horse Pool site during 2012 and 2013. We refer to this emission inventory as "bottom-up" further in the text.

Primary $\mathrm{NO}_{\mathrm{x}}$ emissions are specified as $88 \%$ nitric oxide (NO), $10 \%$ nitrogen dioxide $\left(\mathrm{NO}_{2}\right)$ and $2 \% \mathrm{HNO}_{2}$, which are ratios used within the California Air Resources Board nonpoint sources (http://orthus.arb.ca.gov/calnex/data/discl_ calnex 2010.html). This partitioning was applied to both bottom-up and top-down emission data sets, though model results are shown to be insensitive to this partitioning in Sect. 4.2.3 below. The hourly emissions of the gaseous species were added to the chemical species mixing ratios in the model at every time step during the model integration using temporal profile assignments from cross-reference files in the NEI-2011 version 1 model platform database. The $\mathrm{CH}_{4}$ emissions were indirectly determined from total VOC estimates within NEI-2011 and the total organic gas to reactive organic gas ratios specified within the SPECIATE 4.3 software.

\subsection{Top-down oil/gas sector emission estimates}

The top-down oil/gas emission estimates for the UB region are based on regression slopes of $\mathrm{NO}_{\mathrm{y}}$ and 59 individual VOCs with $\mathrm{CH}_{4}$ observed during daylight hours at the Horse Pool site during the winters of 2012 and 2013. Regressions are determined for observations taken between 10:00 and 16:00 Mountain Standard Time (MST) for two reasons: (1) a broader, more regional representative sample is available during daylight hours, when the boundary layer is well mixed, (2) large transient spikes in $\mathrm{NO}_{\mathrm{y}}, \mathrm{VOC}$ and $\mathrm{CH}_{4}$ observed mostly during stable nighttime conditions that can decrease correlations and influence regression slopes are removed. Absolute emission values are specified by scaling regression slopes with the Uintah County (located in the eastern part of the UB) mean $\mathrm{CH}_{4}$ flux estimate of $55 \times 10^{3} \mathrm{~kg} \mathrm{~h}^{-1}$ as determined from upwind and downwind aircraft transects during one flight in February 2012 (Karion et al., 2013). We distribute this estimated emission over the entire UB, which includes both Uintah and Duchesne (located in the western part of the UB) counties, even though the aircraft measurement used by Karion et al. (2013) covered only the eastern part of the UB. We used this estimate, as it is the only available top-down estimate of $\mathrm{CH}_{4}$ flux for the oil/gas sector in the UB at present. Here, we assume that this emission estimate is representative of 2013 as well. A summary of the regression slopes, $r^{2}$ Pearson correlation coefficients, and partitioning within the photochemical mechanism is presented in the Supplement (Table S1). It should be noted that the VOC to $\mathrm{CH}_{4}$ ratios reported here agree quite well with the independent estimates carried out by Helmig et al. (2014). As explained in that study, VOC emission ratios determined by this regression technique do not account for removal by the $\mathrm{OH}$ radical. Thus, emission estimates, particularly for more reactive VOCs, should be considered lower limits.

No hourly variation is assumed in the top-down emission scenario for the oil/gas sector. Here, the oil/gas emissions are spatially allocated according to well numbers in a given model grid cell, using well location information from the Department of Oil, Gas and Mining, Utah Department of Natural Resources (http://oilgas.ogm.utah.gov/Maps/OG_ Maps.htm), valid as of May 2012. VOC speciation is assumed to be the same for both oil and NG wells. Only wells within Duchesne and Uintah counties are considered. Here, the spatial patterns of $\mathrm{NO}_{\mathrm{x}}$, VOCs, and $\mathrm{CH}_{4}$ emissions from oil and NG operations in both counties are assumed to depend only on well density as a simple first-order approximation. Additional information would be needed to more accurately locate significant isolated emission sources associated with combustion and fugitive processes within the UB. These sources include, but are not limited to, evaporation ponds, diesel generators used in the oil and NG well drilling, oil storage tanks, compressors, NG compressor stations, processing plants and venting operations. We name this emission set "top-down", because it relies on the atmospheric measurements made by an aircraft (Karion et al., 2013) and at the surface site.

Figure $2 \mathrm{a}$ and $\mathrm{b}$ show the spatial distribution of $24 \mathrm{~h}$ averaged total toluene emissions over the UB in the $4 \mathrm{~km}$ resolution model grid from both emissions sets, with the emissions in Fig. $2 b$ being proportional to the spatial density of the oil and NG wells. There are two high emission spots in the region, one in the western part of the UB, and another to the east, south of Horse Pool. 
(a)

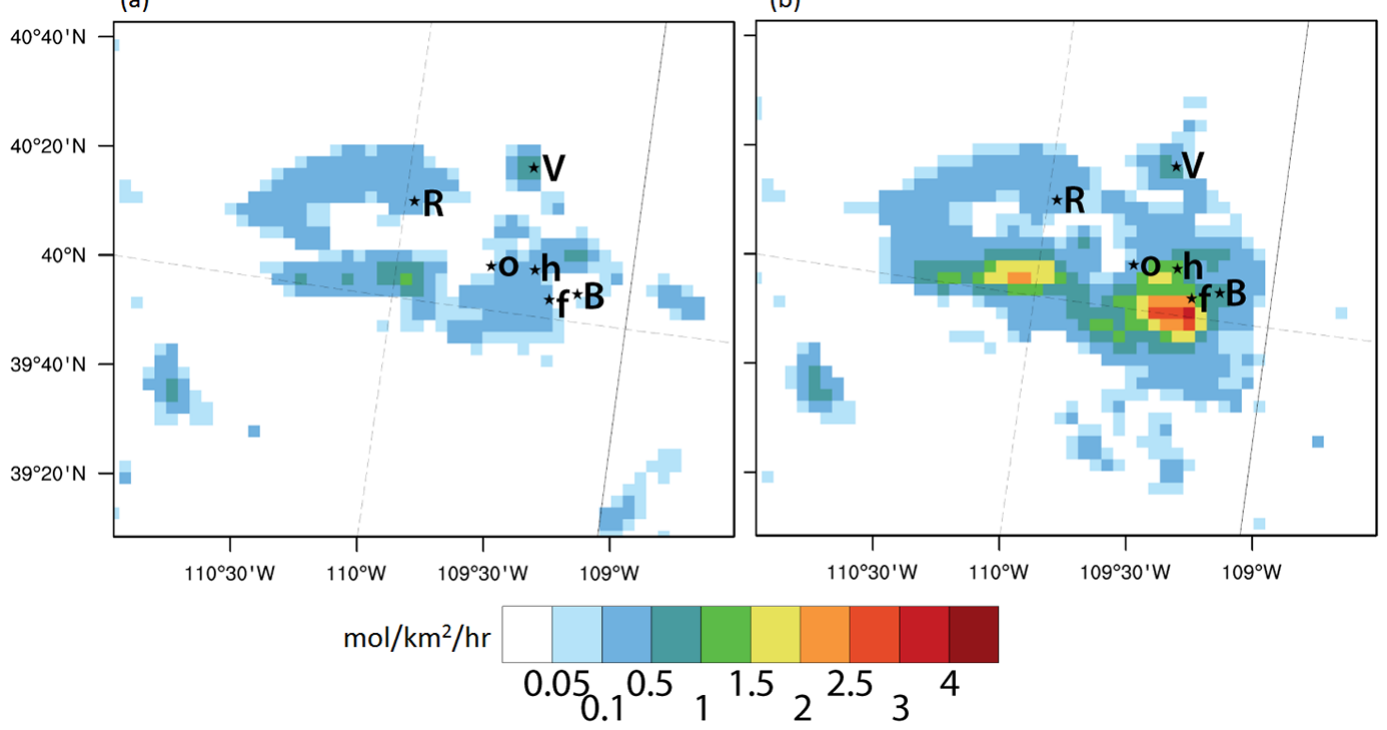

Figure 2. $24 \mathrm{~h}$ averaged anthropogenic emissions of toluene in the Uinta Basin and surroundings: (a) bottom-up (NEI-2011) inventory; (b) top-down emission data set. The letters point to the surface measurement sites: o - Ouray, h - Horse Pool and f - Fantasy Canyon; power plant: B - Bonanza; towns: R - Roosevelt and V - Vernal. The solid line is a border between the states of Colorado and Utah.

Table 2. Anthropogenic emission estimates (in metric tons) for Duchesne and Uintah Counties based on the EPA NEI-2011, NEI-2005 and the top-down estimates for oil and natural gas operations alone. "All other activity" excludes the Bonanza Power Plant emissions. $\mathrm{NO}_{\mathrm{x}}$ emissions are in metric tons/year of $\mathrm{NO}_{2}$ equivalent.

\begin{tabular}{|c|c|c|c|c|c|}
\hline $\begin{array}{l}\text { Emissions } \\
\text { scenarios }\end{array}$ & $\begin{array}{l}\text { Source and } \\
\text { methods }\end{array}$ & $\begin{array}{l}\text { Emissions } \\
\text { sectors }\end{array}$ & $\begin{array}{l}\mathrm{NO}_{\mathrm{x}} \\
\left(\text { tyear }^{-1}\right)\end{array}$ & $\begin{array}{l}\text { Total VOCs } \\
\left.\text { (tyear }^{-1}\right)\end{array}$ & $\begin{array}{l}\mathrm{CH}_{4} \\
\left.\text { (tyear }^{-1}\right)\end{array}$ \\
\hline \multirow[t]{3}{*}{ Bottom-up } & NEI-2011 & Oil and gas & 16448 & 101184 & 100279 \\
\hline & & All other activity & 4095 & 2764 & 1449 \\
\hline & & Bonanza Power Plant & 5978 & 42 & - \\
\hline \multirow[t]{3}{*}{ Top-down } & Regression analysis & Oil and gas & 4158 & 184511 & 482130 \\
\hline & NEI-2005 & All other activity & 2345 & 3198 & 1117 \\
\hline & & Bonanza Power Plant & 6089 & 57 & - \\
\hline
\end{tabular}

Total fluxes of $\mathrm{CH}_{4}$, VOCs and $\mathrm{NO}_{\mathrm{x}}$ from both emission scenarios for the oil/gas and other sectors in the UB are provided in Table $2 . \mathrm{CH}_{4}$ and total VOC emissions for the oil/gas sector within the UB in the bottom-up inventory (NEI-2011) are lower by factors of 4.8 and 1.8 than the top-down estimates, respectively. Conversely, $\mathrm{NO}_{\mathrm{x}}$ emissions are about 4 times higher in the bottom-up inventory. The large difference in $\mathrm{VOC} / \mathrm{NO}_{\mathrm{x}}$ emission ratios between the two products is shown below to have a profound impact on modeled $\mathrm{O}_{3}$ formation within the UB. Table 2 also shows that VOC emissions from the oil/gas sector dominate emissions from all other sources (vehicle, residential, etc.) in the UB, and that $\mathrm{NO}_{\mathrm{x}}$ emissions are dominated by the oil/gas sector in the bottom-up inventory, but not in the top-down emission data set. We assumed $\mathrm{NO}_{\mathrm{y}}$ as an inert species in deriving the $\mathrm{NO}_{\mathrm{x}}$ emissions.

\section{Air quality model description}

The WRF-Chem model is a fully coupled meteorologychemistry model (Grell et al., 2005), and a recent version of the model (version 3.5.1) was used in this study (http://ruc. noaa.gov/wrf/WG11/). The main WRF-Chem model settings are presented in the Supplement (Table S2). The gas-phase chemistry mechanism used here is called "RACM_ESRL" within the WRF-Chem model. The RACM_ESRL gas chemistry scheme is based on the RACM mechanism (Stockwell et al., 1997), which is designed to be suitable for modeling full tropospheric chemistry in remote and polluted re- 
gions. The RACM_ESRL mechanism contains additional chemical reactions, species and updated rate coefficients as discussed within Kim et al. (2009). The mechanism contains a wide range of inorganic and organic species and their intermediates, which are advected and vertically mixed at every time step during model integration, and includes 23 photolysis and 221 chemical reactions. It has been successfully used in previous air quality model studies, e.g., Kim et al. (2009), Kim et al. (2011), and Ahmadov et al. (2012). The advantage of the WRF-Chem model is that the same 3-D model grid, time step and advection scheme are used for both meteorological and chemical variables. Below, we describe some specifications and modifications to the WRFChem 3.5.1 code that are needed for the wintertime UB simulations of 2012 and 2013.

The dry deposition of gas species is parameterized following Erisman et al. (1994). As the default WRF-Chem code was intended to simulate summertime $\mathrm{O}_{3}$, the deposition scheme uses the "snow or ice" type of land use category solely for the areas permanently covered by ice, e.g., the Arctic. The deposition scheme was modified to treat model grid cells as "snow or ice" whenever they are covered by snow. This helps to properly simulate dry deposition fluxes of $\mathrm{O}_{3}$ and other species to the snow-covered ground for the 2013 simulations.

We used the Tropospheric Ultraviolet and Visible (TUV) photolysis scheme (Madronich, 1987) within WRF-Chem. The column density for $\mathrm{O}_{3}$ in the photolysis scheme was set to 270 Dobson units (DU) based on the OMI satellite data set (http://mirador.gsfc.nasa.gov/) for the simulation time period (February 2013) and latitude. Additionally, the photolysis scheme was modified to include the effect of snow on surface albedo. The snow effect on photolysis is not considered in the default WRF-Chem model developed primarily for summertime photochemistry, similar to other air quality models. Based on the measured albedo values during the UBWOS field campaign in 2013, a fixed value of 0.85 was set for the surface albedo in the photolysis module when a given grid cell was covered by snow. The default values of the surface albedo appropriate for bare ground conditions in the TUV scheme lie within the range of $0.05-0.15$, depending on the wavelength. We note that the photolysis scheme in WRF-Chem takes into account surface elevation in calculating the effect of Rayleigh scattering. This could be important for high-elevation sites in the western US, such as the UB and UGRB, which are located at about $1400 \mathrm{~m}$ and $1800 \mathrm{~m}$ a.s.l, respectively.

North American Mesoscale analysis fields (www.emc. ncep.noaa.gov) were used as boundary and initial conditions for the meteorological fields. Idealized vertical profiles were used as initial and boundary conditions to assign the background mixing ratios for some of the long-lived chemical species (McKeen et al., 2002). These idealized profiles are based upon results from the NOAA's Aeronomy Laboratory Regional Oxidation Model. The detailed description of the initial and boundary conditions can be found in the WRFChem user's guide available from http://ruc.noaa.gov/wrf/ WG11/Users_guide.pdf.

The meteorology and chemistry were simultaneously simulated by the WRF-Chem model, initially on the $12 \mathrm{~km}$ resolution domain covering a large part of the western US. For this domain, the bottom-up anthropogenic emissions inventory was used in the simulations. Model simulations were conducted using the same settings and emissions for both the January-February 2012 and 2013 time periods. The second stage of WRF-Chem simulations were conducted on a $4 \mathrm{~km}$ resolution domain by performing one-way downward nesting from the $12 \mathrm{~km}$ domain simulations whereby the output from the coarse domain simulations was used to provide initial and boundary conditions for the meteorological and chemical variables (mixing ratios of the gas species) in the $4 \mathrm{~km}$ model domain. Elevation maps for both model domains are shown in the Supplement (Fig. S1). Hereafter, we present the modeling results solely from simulations done on the $4 \mathrm{~km}$ model grid, as this domain can better represent the "cold pool" conditions and the complex topography in the region.

\section{Discussion of results}

\subsection{Base case simulations}

First, we present $\mathrm{O}_{3}$ modeling results for UBWOS-2012. Figure 3a shows time series of measured and modeled $\mathrm{O}_{3}$ concentrations during 31 January-28 February 2012 at the Horse Pool site. There are three modeling cases here, which were performed in the same way, except for different emission scenarios - bottom-up, top-down, and top-down without any oil/gas emissions in the UB. Observed hourly $\mathrm{O}_{3}$ mixing ratios at the site reach $\sim 40 \mathrm{ppb}$ during afternoon hours, while the variability of daytime $\mathrm{O}_{3}$ from one day to another is small, and none of the emission cases differs markedly. The variability of $\mathrm{O}_{3}$ within the UB is dominated by transport of background $\mathrm{O}_{3}$ into the basin rather than by local chemistry. As noted before, the meteorological conditions did not result in any $\mathrm{O}_{3}$ exceedances during the 2012 field campaign. Maximum $\mathrm{O}_{3}$ values during daytime are reasonably well simulated by both the bottom-up and top-down cases, while the bottom-up inventory shows stronger $\mathrm{O}_{3}$ depletion due to $\mathrm{NO}_{\mathrm{x}}$ titration during nighttime. The model case without the oil/gas emissions is slightly different than the topdown case, indicating a small contribution of the oil/gas sector to $\mathrm{O}_{3}$ production in the UB for 2012 .

Figure $3 \mathrm{~b}$ demonstrates measured and modeled time series of $\mathrm{O}_{3}$ at Horse Pool for 29 January-21 February 2013. The sharp contrast in hourly $\mathrm{O}_{3}$ concentrations between the 2 years is clear. Daytime $\mathrm{O}_{3}$ concentrations on most days exceeded the $\mathrm{O}_{3}$ concentrations observed in 2012 by $2-3$ times. Unlike the 2012 time period, model results with the three emission scenarios for 2013 differ considerably. The simula- 

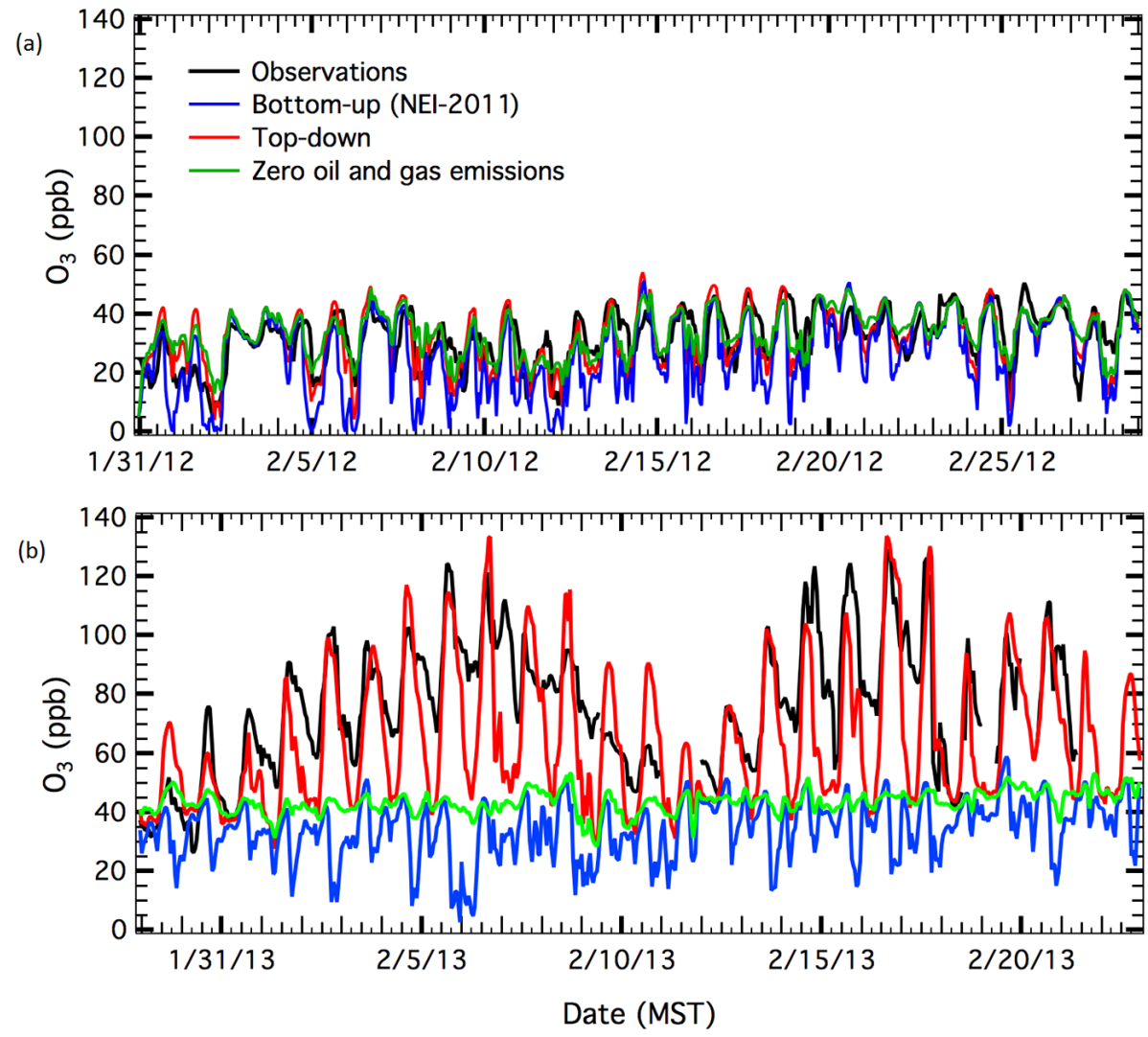

Figure 3. Time series of the measured and modeled hourly $\mathrm{O}_{3}$ mixing ratios at Horse Pool in (a) 2012 and (b) 2013.

tion using the bottom-up emission set cannot capture any of the $\mathrm{O}_{3}$ enhancements observed at Horse Pool in 2013. However, the modeling case using the top-down emissions is able to simulate the high $\mathrm{O}_{3}$ episodes, the multi-day buildup of $\mathrm{O}_{3}$ in the $\mathrm{UB}$, and the removal of $\mathrm{O}_{3}$ from the UB due to meteorological forcing between each high $\mathrm{O}_{3}$ episode. When all the oil/gas emissions are removed from the top-down inventory, model $\mathrm{O}_{3}$ is very close to the background mixing ratios of $\sim 40 \mathrm{ppb}$, indicating a significant contribution of the local oil/gas emissions to high $\mathrm{O}_{3}$ production in the UB in the winter of 2013. We refer to the model simulation for 2013 using the top-down emission scenario as the "base case".

One feature of the base case model $\mathrm{O}_{3}$ time series, not as pronounced as in the observations, are the sharp decreases in late afternoon, with minimums typically occurring between the hours of 03:00 and 06:00 MST. One could easily misinterpret the $\mathrm{O}_{3}$ increase from early morning to late afternoon as being due exclusively to model photochemistry. Model $\mathrm{O}_{3}$ typically peaks between 15:00 and 17:00 MST, and sharply decreases after sunset. From sunset to sunrise both photochemical loss and production are essentially zero and aside from minor titration, $\mathrm{O}_{3}$ is controlled by dynamics and surface deposition. Simulated time series for primary emitted species $\left(\mathrm{NO}_{y}, \mathrm{CH}_{4}\right.$, and toluene) are presented in the Supplement that also show sharp decreases between sunset and the 03:00-06:00 MST time period. These strong decreases in model $\mathrm{O}_{3}$ and other species during nighttime at Horse Pool are caused by katabatic flows within shallow layers near the model surface that advect polluted air down the Green River drainage and replace it with cleaner background air from outside the UB. As discussed in more detail further in the text, with reference to the transport and photochemistry occurring on 5 February 2013, the 3-D model predicts a residual $\mathrm{O}_{3}$ layer from the previous days' photochemistry, effectively trapped within the UB, which also impacts daytime levels.

Statistical evaluations of $\mathrm{O}_{3}$ and other gas-phase species measured at Horse Pool and simulated with the first two emission scenarios and for both 2012 and 2013 are provided in Table 3. Statistical evaluations for meteorological variables at Horse Pool for the same time periods are provided in the Supplement (Table S3). Hereafter, we report the model evaluation statistics for daytime measurements only, between 09:00 and 17:00 MST, since the atmospheric models have difficulties in accurately simulating stable nocturnal planetary boundary layers (PBL) when the PBL depth could be a few meters. These tables also provide the median of observed values for several chemical species at Horse Pool during the 2012 and 2013 field campaigns. The detection methods used to obtain these measurements are described in detail by Warneke et al. (2014). The median of the measured mix- 
Table 3. Statistics for observed and simulated chemical species mixing ratios at Horse Pool, daytime 09:00-17:00 MST hourly average observations for the UBWOS 2012 and 2013 campaigns; $N$ - number of used hourly observations, MO - median of observations, $r$ - Pearson correlation coefficient, MB - median model-observation bias, MMO - median of model over observation.

\begin{tabular}{|c|c|c|c|c|c|c|c|c|c|}
\hline \multirow[t]{2}{*}{ Time period } & \multirow[b]{2}{*}{ Gas species } & \multirow[b]{2}{*}{$\mathrm{N}$} & \multirow[b]{2}{*}{$\mathrm{MO}(\mathrm{ppb})$} & \multicolumn{3}{|c|}{ Bottom-up } & \multicolumn{3}{|c|}{ Top-Down } \\
\hline & & & & $r$ & $\mathrm{MB}(\mathrm{ppb})$ & MMO & $r$ & $\mathrm{MB}(\mathrm{ppb})$ & MMO \\
\hline \multirow{15}{*}{$\begin{array}{l}\text { 31 January } \\
\text {-28 February, } 2012\end{array}$} & Ozone $\left(\mathrm{O}_{3}\right)$ & 261 & 35.9 & 0.79 & 0.24 & 1.01 & 0.77 & 3.64 & 1.11 \\
\hline & Odd oxygen $\left(=\mathrm{O}_{3}+\mathrm{NO}_{2}\right)$ & 162 & 36.8 & 0.69 & 2.83 & 1.08 & 0.76 & 4.08 & 1.11 \\
\hline & Nitrogen oxides $\left(\mathrm{NO}_{\mathrm{x}}\right)$ & 162 & 4.79 & 0.60 & 2.92 & 1.85 & 0.59 & -0.83 & 0.75 \\
\hline & Reactive odd nitrogen $\left(\mathrm{NO}_{\mathrm{y}}\right)$ & 224 & 4.81 & 0.67 & 1.50 & 1.55 & 0.64 & -0.96 & 0.70 \\
\hline & $\mathrm{NO}_{\mathrm{z}}\left(=\mathrm{NO}_{\mathrm{y}}-\mathrm{NO}_{\mathrm{x}}\right)$ & 160 & 1.73 & 0.00 & -0.51 & 0.67 & 0.11 & -0.44 & 0.69 \\
\hline & Methane $\left(\mathrm{CH}_{4}\right)$ & 261 & 2509.0 & 0.65 & -704 & 0.73 & 0.65 & -211. & 0.90 \\
\hline & Ethane $\left(\mathrm{C}_{2} \mathrm{H}_{6}\right)$ & 228 & 49.3 & 0.65 & -30.12 & 0.38 & 0.65 & -7.74 & 0.73 \\
\hline & Toluene $\left(\mathrm{C}_{7} \mathrm{H}_{8}\right)$ & 254 & 0.63 & 0.65 & -0.34 & 0.39 & 0.64 & -0.05 & 0.87 \\
\hline & Xylene $\left(\mathrm{C}_{8} \mathrm{H}_{10}\right)$ & 254 & 0.32 & 0.65 & -0.24 & 0.24 & 0.64 & -0.07 & 0.71 \\
\hline & Propene $\left(\mathrm{C}_{3} \mathrm{H}_{6}\right)$ & 228 & 0.04 & 0.69 & -0.01 & 0.64 & 0.67 & -0.02 & 0.38 \\
\hline & Ethene $\left(\mathrm{C}_{2} \mathrm{H}_{4}\right)$ & 228 & 0.38 & 0.48 & -0.35 & 0.07 & 0.67 & -0.15 & 0.50 \\
\hline & Formaldehyde $\left(\mathrm{CH}_{2} \mathrm{O}\right)$ & 254 & 1.32 & 0.23 & -0.72 & 0.46 & 0.52 & -0.41 & 0.67 \\
\hline & Acetaldehyde $\left(\mathrm{CH}_{3} \mathrm{CHO}\right)$ & 254 & 0.42 & 0.54 & -0.12 & 0.67 & 0.58 & 0.46 & 2.01 \\
\hline & Nitric acid $\left(\mathrm{HNO}_{3}\right)$ & 252 & 0.50 & 0.38 & 0.03 & 1.12 & 0.41 & -0.07 & 0.82 \\
\hline & Peroxyacetyl nitrate (PAN) & 236 & 0.32 & 0.53 & -0.17 & 0.43 & 0.62 & -0.12 & 0.61 \\
\hline \multirow{15}{*}{$\begin{array}{l}29 \text { January } \\
-22 \text { February, } 2013\end{array}$} & Ozone $\left(\mathrm{O}_{3}\right)$ & 191 & 81.9 & 0.33 & -39.80 & 0.51 & 0.85 & -5.25 & 0.93 \\
\hline & Odd oxygen $\left(=\mathrm{O}_{3}+\mathrm{NO}_{2}\right)$ & 191 & 85.8 & 0.83 & -29.19 & 0.67 & 0.85 & -4.65 & 0.95 \\
\hline & Nitrogen oxides $\left(\mathrm{NO}_{\mathrm{x}}\right)$ & 193 & 4.93 & -0.02 & 22.25 & 5.39 & 0.25 & 0.86 & 1.19 \\
\hline & Reactive odd nitrogen $\left(\mathrm{NO}_{\mathrm{y}}\right)$ & 154 & 17.2 & 0.35 & 13.92 & 1.86 & 0.46 & -4.50 & 0.75 \\
\hline & $\mathrm{NO}_{\mathrm{z}}\left(=\mathrm{NO}_{\mathrm{y}}-\mathrm{NO}_{\mathrm{x}}\right)$ & 154 & 12.8 & 0.40 & -9.29 & 0.26 & 0.50 & -5.71 & 0.54 \\
\hline & Methane $\left(\mathrm{CH}_{4}\right)$ & 210 & 7340.0 & 0.29 & -5100 & 0.31 & 0.37 & -2913. & 0.61 \\
\hline & Ethane $\left(\mathrm{C}_{2} \mathrm{H}_{6}\right)$ & 178 & 320.7 & 0.40 & -223.95 & 0.24 & 0.48 & -148.22 & 0.53 \\
\hline & Toluene $\left(\mathrm{C}_{7} \mathrm{H}_{8}\right)$ & 204 & 4.01 & 0.32 & -2.95 & 0.24 & 0.44 & -1.78 & 0.55 \\
\hline & Xylene $\left(\mathrm{C}_{8} \mathrm{H}_{10}\right)$ & 204 & 1.66 & 0.30 & -1.35 & 0.17 & 0.44 & -0.90 & 0.43 \\
\hline & Propene $\left(\mathrm{C}_{3} \mathrm{H}_{6}\right)$ & 192 & 0.20 & 0.23 & -0.09 & 0.54 & 0.16 & -0.14 & 0.22 \\
\hline & Ethene $\left(\mathrm{C}_{2} \mathrm{H}_{4}\right)$ & 192 & 2.26 & 0.24 & -2.21 & 0.02 & 0.43 & -1.44 & 0.35 \\
\hline & Formaldehyde $\left(\mathrm{CH}_{2} \mathrm{O}\right)$ & 204 & 4.85 & 0.12 & -3.82 & 0.18 & 0.10 & -2.34 & 0.53 \\
\hline & Acetaldehyde $\left(\mathrm{CH}_{3} \mathrm{CHO}\right)$ & 204 & 4.41 & 0.70 & -2.79 & 0.35 & 0.73 & 1.03 & 1.27 \\
\hline & Nitric acid $\left(\mathrm{HNO}_{3}\right)$ & 179 & 4.46 & 0.18 & -2.77 & 0.35 & 0.22 & -3.05 & 0.26 \\
\hline & Peroxyacetyl nitrate (PAN) & 200 & 2.00 & 0.78 & -1.66 & 0.20 & 0.78 & -0.11 & 0.90 \\
\hline
\end{tabular}

ing ratios of primary and secondary chemical species highlight the contrast in pollutant levels in the UB between the two consecutive years.

The evaluation statistics reveal that the model captures the temporal variability of primary species better in 2012 than in 2013. This could be caused by the fact that, during 2013, turbulent mixing and advection were much weaker than in 2012, and uncertainties in the spatial representation of emissions would affect the correlations for primary species more strongly in the 2013 evaluations. This would likely be the case for both the bottom-up and top-down emission cases. Primary species such as $\mathrm{NO}_{\mathrm{y}}$ and some non-methane hydrocarbons are somewhat underestimated during daytime for the top-down emission case in both 2012 and 2013. Table 3 clearly demonstrates that the bottom-up inventory leads to a stronger model underestimation of $\mathrm{CH}_{4}$ in 2012 compared to the top-down emission estimates. The evaluation of $\mathrm{CH}_{4}$ simulations at a ground site provides an independent validation of the $\mathrm{CH}_{4}$ flux estimates from the oil and NG operations in the UB determined by using aircraft measurements. The discrepancy between the emission scenarios in terms of $\mathrm{CH}_{4}$ simulations widens in 2013 simulations (Table 3), when high $\mathrm{CH}_{4}$ levels were observed at Horse Pool. However the top-down emission case still underestimates $\mathrm{CH}_{4}$ levels by $\sim 40 \%$. This model underestimation may be caused by two sources of error that could potentially offset each other. First, as stated above, the $\mathrm{CH}_{4}$ flux estimate of Karion et al. (2013) used to scale the primary emissions is likely a lower limit, since the estimate is limited to a single day of aircraft sampling that only sampled emissions from the oil and NG operations emissions in the eastern part of the UB. Second, biases in the model meteorological fields, such as wind speed and mixing layer height, could be affecting either year's statistics.

Evaluation of the model for other gaseous species at Horse Pool for the two emission cases reveals that the bottom-up 
emissions (NEI-2011) lead the model to strongly overestimate the $\mathrm{NO}_{\mathrm{y}}$ concentrations, while the VOCs are greatly underestimated (Table 3). Using the top-down emission scenario, the model explains the temporal variability in the primary species such as $\mathrm{NO}_{\mathrm{y}}$, alkanes (ethane), and aromatics (toluene and xylene) better than the bottom-up inventory in 2013, while the two cases are not that different in 2012. This shows the advantage of the top-down emission estimates compared with the bottom-up (NEI-2011) case for the oil/gas emissions in the UB. The model captures both the temporal variability and the daytime values of secondary species such as $\mathrm{O}_{3}$, peroxyacyl nitrates (PAN) and acetaldehyde $\left(\mathrm{CH}_{3} \mathrm{CHO}\right)$ in 2013 quite well.

Table 3 reveals that, for 2012, both emission cases show very similar correlations for the daytime $\mathrm{O}_{3}$ concentrations, as the $\mathrm{O}_{3}$ concentrations were slightly affected by local emissions and photochemistry. However, in 2013, the top-down emission case exhibits a profoundly better correlation than the bottom-up case. The top-down emission case captures both the magnitude and variance of the daytime $\mathrm{O}_{3}$ values at Horse Pool well. In Table 3, the statistics for odd oxygen $\left(\mathrm{O}_{\mathrm{x}}=\mathrm{O}_{3}+\mathrm{NO}_{2}\right)$ are also shown. This helps to identify the role of $\mathrm{O}_{3}$ titrated by freshly emitted $\mathrm{NO}_{\mathrm{x}}$ in the model and observation. The bias statistics show that the topdown emission scenario allows the model to capture the secondary species, which are products of the photochemistry. Conversely, the bottom-up inventory results in strong underestimation of the secondary species during 2013.

The statistical comparisons in Table 3 for reactive nitrogen species show a marked difference between 2012 and 2013 for observed levels of $\mathrm{NO}_{\mathrm{y}}$. Median $\mathrm{NO}_{\mathrm{y}}$ levels are more than a factor of 3.5 higher in 2013 compared to 2012, yet median $\mathrm{NO}_{\mathrm{x}}$ levels are nearly identical. The differences in $\mathrm{NO}_{\mathrm{x}} / \mathrm{NO}_{\mathrm{y}}$ partitioning between the 2 years is qualitatively reproduced in the top-down inventory results, but difference for individual $\mathrm{NO}_{\mathrm{y}}$ species are apparent. The statistical comparisons in Table 3 for reactive nitrogen species show a marked difference between 2012 and 2013 for the top-down emission case. Both years show a 25 to $30 \%$ low bias in $\mathrm{NO}_{\mathrm{y}}$. One would expect biases in individual $\mathrm{NO}_{\mathrm{y}}$ species to reflect the bias of $\mathrm{NO}_{\mathrm{y}}$ itself, which is the case for $\mathrm{NO}_{\mathrm{x}}$, nitric acid $\left(\mathrm{HNO}_{3}\right)$, and PAN in 2012. However, in 2013, $\mathrm{NO}_{\mathrm{x}}$ shows a positive bias, and $\mathrm{HNO}_{3}$ is significantly underpredicted relative to $\mathrm{NO}_{\mathrm{y}}$. The $\mathrm{HNO}_{3}$ underprediction can be explained by high $\mathrm{HNO}_{3}$ deposition velocities in the default version of the WRF-Chem model used here. Measurements of $\mathrm{HNO}_{3}$ deposition to snow indicate a low deposition velocity at cold temperatures but increases with increasing temperature (Johansson and Granat, 1986), and even $\mathrm{HNO}_{3}$ emissions from snow due to heterogeneous conversion of other reactive nitrogen species to nitrate at the snow surface (Dibb et al., 1998). The overprediction of $\mathrm{NO}_{\mathrm{x}}$ may likewise be related to uncertainties in the deposition of $\mathrm{NO}_{2}$ to the snow-covered surface, but as discussed further below in the model sensitivity section, nighttime heterogeneous conversion of $\mathrm{N}_{2} \mathrm{O}_{5}$ to aerosol,

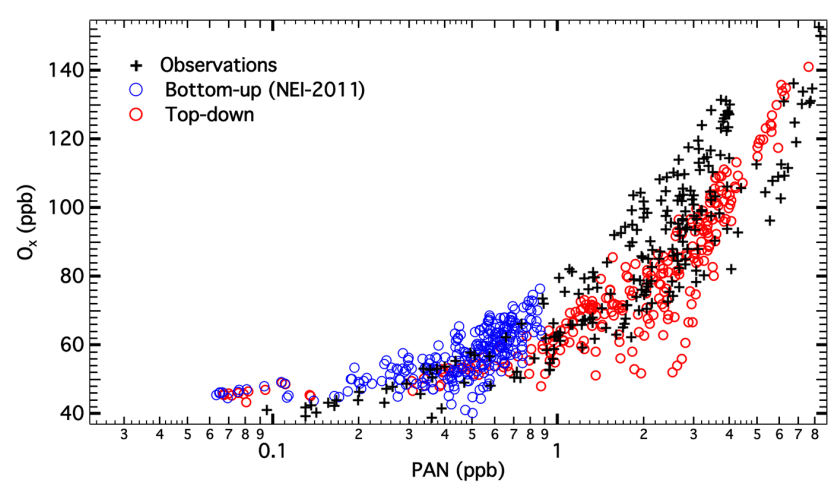

Figure 4. Scatterplot of measured and modeled hourly $\mathrm{O}_{\mathrm{x}}$ vs. PAN mixing ratios during daytime (09:00-17:00 MST), 29 January-22 February 2013 at Horse Pool.

which is not included in our base model configuration, could explain part of the $\mathrm{NO}_{\mathrm{x}}$ discrepancy during 2013 .

In order to demonstrate how well the model parameterizes the photochemistry in both emission cases, we plot measured and modeled $\mathrm{O}_{\mathrm{x}}$ vs. PAN during the daytime for 2013 (Fig. 4). As seen from the scatter plot, the base case (topdown emission scenario) is able to predict the observed relationship between $\mathrm{O}_{\mathrm{x}}$ and PAN. The model case with the bottom-up inventory also matches the observed $\mathrm{O}_{\mathrm{x}}-\mathrm{PAN}$ relationship, but over a much smaller concentration range. As only the top-down emission inventory can explain the high $\mathrm{O}_{3}$ in the UB in 2013, we analyze this base case model scenario in more detail below.

The time period shown in Fig. 3b consists of three distinct episodes with high $\mathrm{O}_{3}$ measurements. We group these episodes as follows: the first and longest episode covers the 29 January-8 February time period. The other two episodes cover 12-17 February and 19-21 February 2013. Between the episodes, synoptic-scale surface low-pressure systems were present, which led to the partial clearing of $\mathrm{O}_{3}$ and other pollutants out of the UB. Such meteorological conditions occurred prior to 29 January and between the stagnation episodes. Weather maps in Supplement Fig. S2 show synoptic situations associated with a frontal passage and stagnation episode that occurred in the UB during UBWOS-2013. Hereafter, we focus on the 29 January-8 February stagnation period. Meteorological conditions associated with $\mathrm{O}_{3}$ buildup for other time periods are very similar to this episode. We also provide evaluations for some of the meteorological variables over the same time period in the Supplement.

Figure $5 \mathrm{a}$ and $\mathrm{b}$ illustrate the simulated $\mathrm{O}_{3}$ distribution within the UB during a high ozone event. Modeled $\mathrm{O}_{3}$ mixing ratios and horizontal wind vectors over the vertical plane across the Ouray and Horse Pool sites (Fig. 1) are shown at night (05:00 MST) and in the afternoon (15:00 MST) on 5 February 2013, a typical stagnation day when $\mathrm{O}_{3}$ levels reached 124.2 ppb at Horse Pool (Fig. 3b). The plots show the very low wind speed inside the UB, demonstrating the wind 


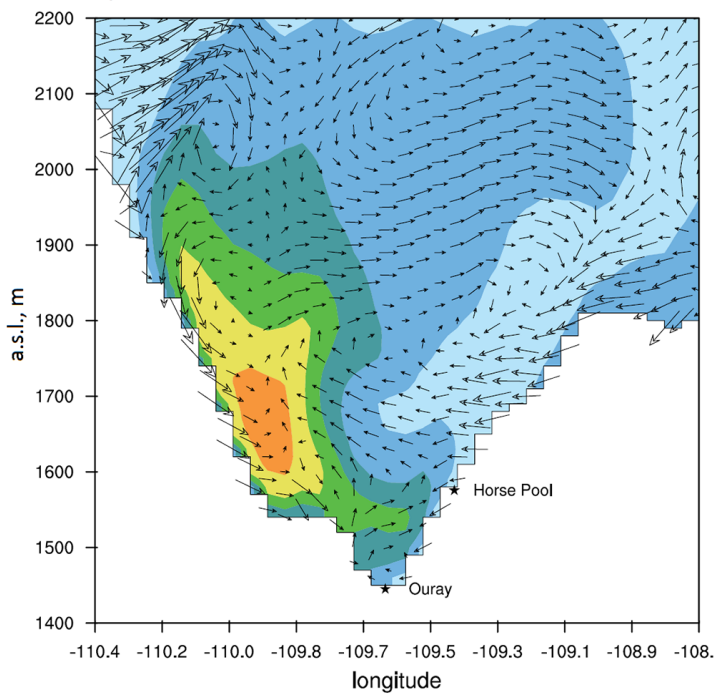

b)

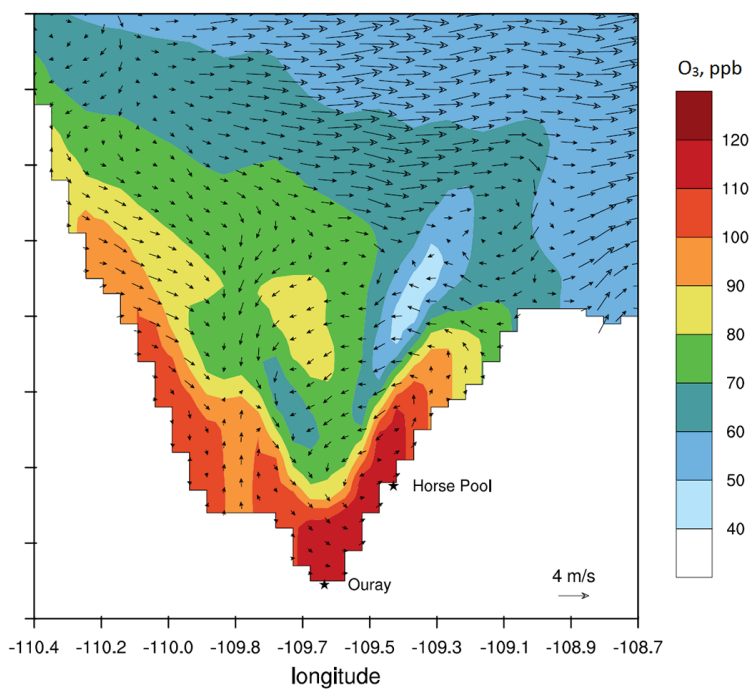

Figure 5. Simulated $\mathrm{O}_{3}$ distribution and wind vectors over the UB (west-to-east direction in the WRF grid). The Horse Pool and Ouray surface stations along the cross section are shown; (a) early morning (05:00 MST), and (b) afternoon (15:00 MST) on 5 February 2013. The vertical wind components were multiplied by 100 for illustration of the wind vectors.

regime during a VCP type situation. Figure 5a shows the high $\mathrm{O}_{3}$ from the previous days' photochemistry in early morning above the western slope within a residual layer. The highest $\mathrm{O}_{3}$ mixing ratio is simulated at $\sim 100 \mathrm{~m}$ above the ground at night. The downslope terrain flows converge at the bottom of the UB at night. Later, the layer enriched with $\mathrm{O}_{3}$ and other pollutants aloft is moved to the eastern part of the UB during the morning hours. As we show in the Supplement (Fig. S3c), the wind speed of the nocturnal drainage flows over the UB are overestimated at Horse Pool and possibly elsewhere. This overestimation likely causes a stronger and faster drainage of the air masses near the ground at night, than what was observed. These strong nighttime drainage flows also displace primary emitted species with background concentrations at night.

Then, the shallow vertical mixing layer that developed along the slopes of the UB dilutes the pollutants aloft within itself. The afternoon $\mathrm{O}_{3}$ distribution for the same vertical plane shows the horizontal and vertical extent of the $\mathrm{O}_{3}$ build up in the UB (Fig. 5b). $\mathrm{O}_{3}$ mixing ratios reached $\sim 120 \mathrm{ppb}$ over Horse Pool and Ouray at 15:00 MST. The highest $\mathrm{O}_{3}$ buildup is simulated between these two sites. The mixed layer with high $\mathrm{O}_{3}(>100 \mathrm{ppb})$ is $\sim 100 \mathrm{~m}$ thick during the daytime. High $\mathrm{O}_{3}$ buildup $(\sim 100 \mathrm{ppb})$ is simulated over the western part of the UB, reaching an elevation as high as $1900 \mathrm{~m}$ a.s.l. on the western slope. Another prominent feature on this particular day in the vertical $\mathrm{O}_{3}$ distribution is the depletion of $\mathrm{O}_{3}$ at $\sim 1800 \mathrm{~m}$ a.s.l. apparent in the eastern part due to $\mathrm{O}_{3}$ titration caused by high $\mathrm{NO}_{\mathrm{x}}$ emissions from Bonanza Power Plant. Due to shallow mixing layers at the surface, the plume from the power plant's stack does not mix with the air near the ground. Photographic evidence during UBWOS-2013 shows thermally buoyant plumes from Bonanza Power Plant extending well above the shallow PBL during the stagnant meteorological situations (Oltmans et al., 2014b). The WRF-Chem simulation appears to underpredict the Bonanza plume rise by $\sim 150 \mathrm{~m}$ and overpredict the vertical spread of the emissions from the power plant. Later, we quantify the contribution of the $\mathrm{NO}_{\mathrm{x}}$ emissions from this power plant to $\mathrm{O}_{3}$ at the Horse Pool site within a sensitivity simulation that removes Bonanza Power Plant emissions. It is apparent from Fig. 5a and $b$ that the $\mathrm{O}_{3}$ mixing ratios transported above the UB, advected predominantly by westerly winds, are low, close to background $\mathrm{O}_{3}$ levels.

Figure $6 \mathrm{a}$ and $\mathrm{b}$ present time series of the observed and modeled $\mathrm{O}_{3}$ vertical distributions over Horse Pool. The observed distribution was obtained by interpolating the eight $\mathrm{O}_{3}$ tethersonde measurements for 5 February 2013. The modeled $\mathrm{O}_{3}$ values were extracted at the time of the vertical profile measurements and then interpolated. The observed temporal variability of $\mathrm{O}_{3}$ over Horse Pool (Fig. 6a) shows that the strong $\mathrm{O}_{3}$ buildup starts at $\sim 10: 00 \mathrm{MST}$, and it is confined to a shallow mixing layer $(\sim 100 \mathrm{~m}$ thick $)$. The $\mathrm{O}_{3}$ aloft is found over Horse Pool around 10:00-15:00 MST. The model shows similar characteristics for vertical $\mathrm{O}_{3}$ profiles during the day. A layer aloft with high $\mathrm{O}_{3}$ is seen at $\sim 350 \mathrm{~m}$ above the ground in the model. The depletion of $\mathrm{O}_{3}$ above is caused by titration of $\mathrm{O}_{3}$ by Bonanza Power Plant $\mathrm{NO}_{\mathrm{x}}$ emissions at higher altitudes. Figures $5 \mathrm{a}, \mathrm{b}$ and $6 \mathrm{a}, \mathrm{b}$ provide insight into the timing and horizontal and vertical distributions of high $\mathrm{O}_{3}$ observed near the surface and above in the UB. The model predicted vertical distribution of $\mathrm{O}_{3}$, 
and its recirculation in the west-east direction within the UB is qualitatively confirmed by the tethersonde measurements taken at Horse Pool. Moreover, the tethersonde comparisons confirm that the Horse Pool surface $\mathrm{O}_{3}$ measurements are quite representative of the overall $\mathrm{O}_{3}$ production in the eastern $\mathrm{UB}$, and that the diurnal pattern of $\mathrm{O}_{3}$ recirculation to Horse Pool is not localized to just that site. Figure 6a and $\mathrm{b}$ also show PBL heights determined by using the measured and simulated virtual potential temperature vertical profiles on 5 February 2013. The PBL height estimates for all the daytime tethersonde launchings during the UBWOS-2013 and their comparison with the model output are provided in the Supplement (Fig. S5).

In order to verify how well the base model case with the top-down emission scenario simulates $\mathrm{O}_{3}$ at other locations, Figure $7 \mathrm{a}$ and $\mathrm{b}$ show comparisons of $\mathrm{O}_{3}$ measurements near the ground at the Ouray and Fantasy Canyon locations (shown in Fig. 1). The observed $\mathrm{O}_{3}$ concentrations are derived from the tethersonde launches conducted during daytime (09:00-17:00 MST), windowed for the evaluation time period (29 January-8 February 2013). The figures present model $\mathrm{O}_{3}$ mixing ratios at the times when the tethersonde measurements took place near the ground. The daytime $\mathrm{O}_{3}$ time series at both sites exhibit a day-to-day variability similar to the Horse Pool measurements. The observed daily maximum $\mathrm{O}_{3}$ mixing ratios reached $\sim 160 \mathrm{ppb}$ at Ouray and $\sim 140$ ppb at Fantasy Canyon on 5 and 6 February 2013, respectively. Later on, maximum daytime $\mathrm{O}_{3}$ values started decreasing at both sites. The base model case captures the elevated afternoon $\mathrm{O}_{3}$ concentrations at Ouray and Fantasy Canyon quite well. The time series comparisons at all three surface sites show that the WRF-Chem model is able to simulate the spatial and temporal distribution of daytime $\mathrm{O}_{3}$ in the eastern portion of the UB reasonably well.

\subsection{Sensitivity simulations}

Here, we present different sensitivity simulations to parse out the relative contribution of various factors to $\mathrm{O}_{3}$ production within the base case simulation. For this purpose, we performed multiple model simulations for the same stagnation episode (29 January-8 February 2013) using the same model settings and boundary conditions in the $4 \mathrm{~km}$ resolution domain as the base case. These simulations were conducted by applying perturbations to the emissions, photochemical mechanisms and physical processes, while all other settings were kept the same as for the base case simulation. We confine our analysis to $\mathrm{O}_{3}$ at the Horse Pool site. It should be noted that the sensitivities of $\mathrm{O}_{3}$ to various perturbations are not additive among the various cases, as the $\mathrm{O}_{3}$ chemistry is very nonlinear.

In order to quantify the impact of the perturbation cases, we use the difference between the base case and the case without the oil/gas emissions (shown in Fig. 3b) as a normalizing constant. We define the impact ratio (IR) for a given simulation case as follows:

$\mathrm{IR}^{\text {case }}=\frac{\left|\mathrm{MB}\left(\mathrm{O}_{3}^{\text {base }}\right)-\mathrm{MB}\left(\mathrm{O}_{3}^{\text {case }}\right)\right|}{\left|\mathrm{MB}\left(\mathrm{O}_{3}^{\text {base }}\right)-\mathrm{MB}\left(\mathrm{O}_{3}^{\text {no oil } / \text { gas }}\right)\right|}$.

Here, we use the median bias (MB) for $\mathrm{O}_{3}$ mixing ratios for a given model case as the diagnostic variable. Table 4 presents both MB and IR values for all the model cases discussed hereafter. The IR for the base case (B0) is equal to 0 , and the IR for the no oil/gas emission case is equal to 1 (B1), by definition.

\subsubsection{Sensitivity to the photolysis rates}

As discussed in Sect. 3, the WRF-Chem model was modified to include the effect of surface albedo due to surface snow. We tested the model with the same settings as in the base case, but with default bare ground surface albedo conditions used. The test simulation (P1) shows that, in this case, the IR value is $\approx 1$ (Table 4 ), and this case fails to capture the $\mathrm{O}_{3}$ production in the UB. Hence, we cannot simulate the high $\mathrm{O}_{3}$ levels without taking into consideration the enhancement in photolysis rates due to the reflected solar irradiance from the snow cover. This result is similar to the box model cases reported for VOC sensitive regimes for the regions with high oil and NG emissions (Carter and Seinfeld, 2012; Edwards et al., 2013).

We also checked the impact of overhead $\mathrm{O}_{3}$ column density on the simulated $\mathrm{O}_{3}$ concentrations at the surface. The case (P2) includes a test simulation where the column $\mathrm{O}_{3}$ density was set to 350 DU in the TUV scheme, as in the default WRF-Chem code. This $30 \%$ increase reduces modeled $\mathrm{O}_{3}$, with an IR for this case of 0.22 (Table 4). Thus, model $\mathrm{O}_{3}$ at Horse Pool is somewhat sensitive to the overhead $\mathrm{O}_{3}$ column, but the model can still simulate the strong $\mathrm{O}_{3}$ buildup in the UB.

\subsubsection{Sensitivity to the surface deposition processes}

As noted in Sect. 3, the presence of a snow layer on the ground also modifies the dry deposition of the gas-phase species. To quantify the contribution of this process to surface $\mathrm{O}_{3}$, we performed a simulation where the modeled dry deposition velocities for all the gas species are the same as on bare ground, i.e., the default WRF-Chem model. The IR for this case (D1 in Table 4) is significant (0.48). The model in this case still predicts a strong diurnal cycle in $\mathrm{O}_{3}$ at the surface, but with daytime maximums reduced: 20 to $35 \mathrm{ppb}$.

Another simulation (D2) was done by setting the dry deposition velocity of $\mathrm{O}_{3}$ to zero in the model. During the UBWOS-2013 field campaign, the measured daytime deposition velocities were $\sim 0.002-0.005 \mathrm{~cm} \mathrm{~s}^{-1}$ over the snowy surface. These values are lower than what the model simulations show for $\mathrm{O}_{3}$ dry deposition velocities $\left(\sim 0.02 \mathrm{~cm} \mathrm{~s}^{-1}\right)$ 

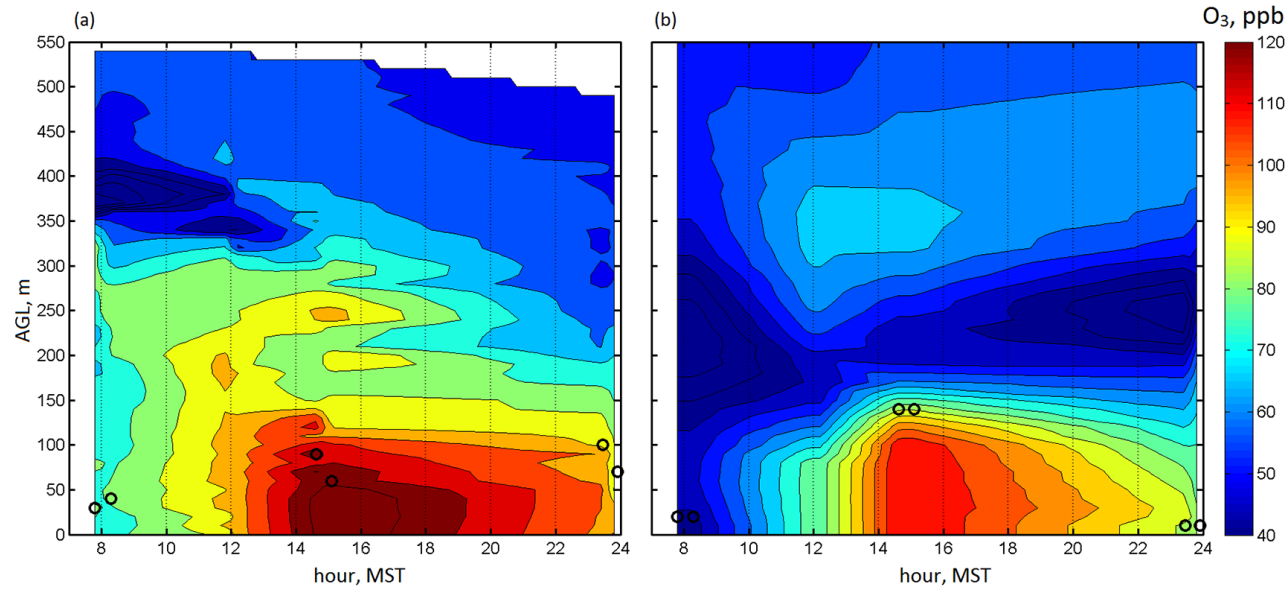

Figure 6. Vertical $\mathrm{O}_{3}$ distribution above the Horse Pool site, 5 February 2013: (a) measured by the tethersonde; (b) modeled. There are data from eight tethersonde profiles in panel (a). The $\mathrm{O}_{3}$ mixing ratios were interpolated for other times of the day. Black circles show PBL heights determined using the vertical gradient of the virtual potential temperature. For the third and fourth tethersonde launchings, the meteorological data are not available to calculate the PBL heights.

Table 4. Median bias (MB) and impact ratio (IR) for $\mathrm{O}_{3}$ at Horse Pool for various perturbations to the base model. Model results are compared against hourly average observations between 09:00 and 17:00 MST, 29 January-8 February 2013.

\begin{tabular}{|c|c|c|c|}
\hline $\begin{array}{l}\text { Modeling } \\
\text { case ID }\end{array}$ & $\begin{array}{l}\text { Model perturbation } \\
\text { case }\end{array}$ & $\begin{array}{r}\mathrm{MB} \\
(\mathrm{ppb})\end{array}$ & IR \\
\hline B0 & Base simulation (top-down emissions) & -6.32 & - \\
\hline B1 & Base simulation, all oil/gas emissions set to zero & -35.81 & 1.00 \\
\hline \multicolumn{4}{|l|}{ Photolysis } \\
\hline P1 & Snow albedo replaced by bare-ground albedo & -37.06 & 1.04 \\
\hline $\mathrm{P} 2$ & Overhead column $\mathrm{O}_{3}$ increased by $30 \%$ & -12.94 & 0.22 \\
\hline \multicolumn{4}{|l|}{ Deposition } \\
\hline D1 & No snow effect on dry deposition of gas species & -20.49 & 0.48 \\
\hline D2 & $\mathrm{O}_{3}$ deposition velocity set to zero & -0.62 & 0.19 \\
\hline \multicolumn{4}{|l|}{ Emissions } \\
\hline E1 & Oil/gas $\mathrm{NO}_{\mathrm{x}}$ emissions decreased by $30 \%$ & -6.57 & 0.01 \\
\hline E2 & Oil/gas VOC emissions decreased by $30 \%$ & -16.06 & 0.33 \\
\hline E3 & Oil/gas $\mathrm{NO}_{\mathrm{x}}$ and VOC emissions decreased by $30 \%$ & -14.23 & 0.27 \\
\hline E4 & Oil/gas $\mathrm{NO}_{\mathrm{x}}$ emissions decreased by $66.67 \%$ & -10.42 & 0.14 \\
\hline E5 & Oil/gas $\mathrm{NO}_{\mathrm{x}}$ emissions set to zero & -19.56 & 0.45 \\
\hline E6 & Bonanza Power Plant $\mathrm{NO}_{\mathrm{x}}$ emissions removed & -7.22 & 0.03 \\
\hline E7 & Oil/gas alkane ( $>\mathrm{C} 2$ ) VOC emissions set to zero & -19.41 & 0.44 \\
\hline E8 & Oil/gas aromatic VOC emissions set to zero & -17.15 & 0.37 \\
\hline E9 & $\mathrm{Oil} /$ gas $\mathrm{CH}_{2} \mathrm{O}$ emissions set to zero & -11.66 & 0.18 \\
\hline E10 & Oil/gas $\mathrm{CH}_{2} \mathrm{O}$ emissions, $\mathrm{HNO}_{2}$ and $\mathrm{NO}_{2}$ in $\mathrm{NO}_{\mathrm{x}}$ emissions set to zero & -13.09 & 0.23 \\
\hline \multicolumn{4}{|l|}{ Chemistry } \\
\hline $\mathrm{C} 1$ & $\mathrm{O}^{1} \mathrm{D}+\mathrm{H}_{2} \mathrm{O} \rightarrow 2 \mathrm{OH}$ reaction rate set to zero & -13.66 & 0.25 \\
\hline $\mathrm{C} 2$ & $\mathrm{CH}_{2} \mathrm{O}+h v \rightarrow \mathrm{CO}+2 \mathrm{HO}_{2}$ photolysis channel set to zero & -21.42 & 0.52 \\
\hline $\mathrm{C} 3$ & $\mathrm{NO}_{3}+\mathrm{NO}_{2} \rightarrow 2 \mathrm{HNO}_{3}$ (heterogeneous $\mathrm{NO}_{\mathrm{x}}$ loss upper limit) & -11.96 & 0.19 \\
\hline
\end{tabular}



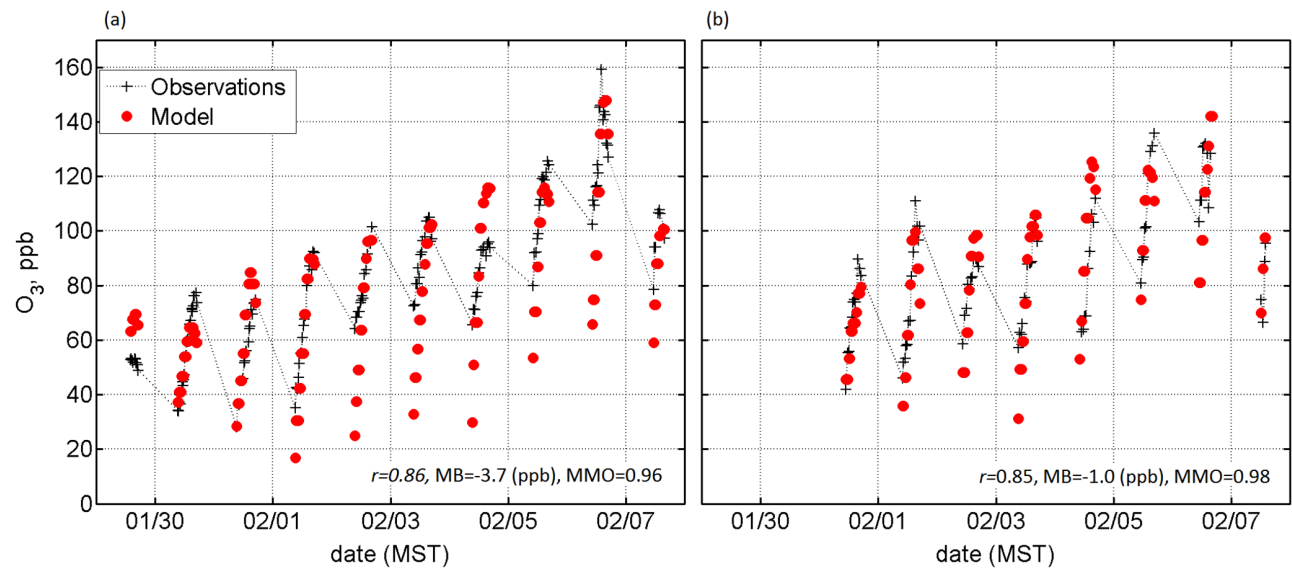

Figure 7. Time series of the daytime (09:00-17:00 MST) $\mathrm{O}_{3}$ mixing ratios measured near the surface by tethersondes and modeled at the (a) Ouray and (b) Fantasy Canyon sites in the winter of 2013. The locations of these tethersonde launchings are shown in Fig. 1. Here, the modeled $\mathrm{O}_{3}$ values are shown solely for the times when the tethersonde measurements were conducted.

over snowy ground during daytime. Given the possible uncertainty with the $\mathrm{O}_{3}$ deposition over snow, this test simulation provides us with a low end estimate in terms of $\mathrm{O}_{3}$ deposition's impact. The simulation shows that if there is no $\mathrm{O}_{3}$ loss to the ground, the model captures the daytime $\mathrm{O}_{3}$ concentrations even better than the base case $(\mathrm{MB}=-0.6 \mathrm{ppb}$ vs. the base case MB of $-6.3 \mathrm{ppb}$ ), with an IR for this case of 0.19 .

\subsubsection{Sensitivity to the emission perturbations}

Since emissions from the oil/gas sector play a crucial role in driving up $\mathrm{O}_{3}$ in the $\mathrm{UB}$, we further investigate the influence of various emission scenarios on $\mathrm{O}_{3}$ at Horse Pool. First, we check the sensitivity of $\mathrm{O}_{3}$ to possible $\mathrm{NO}_{\mathrm{x}}(\mathrm{E} 1)$ and VOC (E2) emission reductions. This potentially has an important implication for air quality regulations, to find out what emission reduction strategies are more efficient and cost effective to mitigate $\mathrm{O}_{3}$ exceedances of NAAQS. The E2 simulation in Table 4 reveals that the reduction of VOC emissions by $30 \%$ reduces $\mathrm{O}_{3}$ nearly one-to-one on a percentage basis $(\mathrm{IR}=0.33)$. Reducing the $\mathrm{NO}_{\mathrm{x}}$ emissions from the oil/gas sector by the same amount $(E 1, I R=0.01)$ results in essentially no reduction in $\mathrm{O}_{3}$. The simulation reducing $\mathrm{NO}_{\mathrm{x}}$ emissions by a factor of 3 (E4) slightly reduces model $\mathrm{O}_{3}$ production ( $(\mathrm{R}=0.14)$, but is still significantly less effective than the $30 \%$ VOC reduction case $\mathrm{E} 2$. It is only when $\mathrm{NO}_{\mathrm{x}}$ emissions from the oil/gas sector are completely removed (E5, $\mathrm{IR}=0.45$ ) that a significant reduction in $\mathrm{O}_{3}$ occurs without eliminating any VOCs. We additionally note that, when all oil/gas sector $\mathrm{NO}_{\mathrm{x}}$ emissions are removed, the model still predicts 2 to $3 \mathrm{ppb}$ daytime $\mathrm{NO}_{\mathrm{x}}$. The remaining $\mathrm{NO}_{\mathrm{x}}$ at Horse Pool is $57 \%$ from the towns and highways on the northern edge of the basin, with Bonanza Power Plant accounting for the remainder. Thus, under the high VOC emissions within the UB these levels of $\mathrm{NO}_{\mathrm{x}}$ are sufficient to sup- port more than half the $\mathrm{O}_{3}$ buildup seen in the observations and base case model.

The model case $(E 6, I R=0.03)$ shows that the impact of $\mathrm{NO}_{\mathrm{x}}$ emissions from Bonanza Power Plant on $\mathrm{O}_{3}$ concentrations at Horse Pool is very small. This IR is an upper limit, since the model appears to underpredict the height of the Bonanza source plume, as discussed earlier. A model budget of $\mathrm{NO}_{\mathrm{y}}$ in the UB deduced from simulations E5 and E6 shows that $66 \%$ of simulated $\mathrm{NO}_{\mathrm{y}}$ is due to oil and gas activity, $10 \%$ is due to Bonanza Power Plant, and $24 \%$ is due to vehicle and urban emissions (Vernal and Roosevelt, UT) from the edge of the basin. Again, this $10 \%$ contribution from Bonanza can be considered an upper limit to its actual contribution.

Simulations E7 and E8 quantify the contribution of alkane $(>\mathrm{C} 2)$ and aromatic VOC species to model $\mathrm{O}_{3}$ by zeroing out the oil/gas sector emissions for each of these VOC classes. The results show their relative contributions to be nearly the same, and comparable to case E5 where all the oil/gas sector $\mathrm{NO}_{\mathrm{x}}$ emissions are removed. Yet, the VOC measurements (Table 3) and top-down inventory (Table S1 in the Supplement) show that aromatic emissions are much smaller than alkane emissions. On a molar basis total aromatic emissions are only $\sim 8 \%$ of the emissions of all alkanes having greater than or equal to 5 carbon atoms. The disproportionate impact of oil/gas sector aromatics on wintertime $\mathrm{O}_{3}$ production has been documented by a box modeling study for another basin, the UGRB in Wyoming (Carter and Seinfeld, 2012).

Another uncertainty is the role of primary formaldehyde $\left(\mathrm{CH}_{2} \mathrm{O}\right)$ emissions. $\mathrm{CH}_{2} \mathrm{O}$ is largely produced by photochemistry, and has a lifetime of less than a couple of hours during midday. Therefore, it is hard to segregate the fraction of $\mathrm{CH}_{2} \mathrm{O}$ due to primary emissions using atmospheric measurements. The high correlation of daytime $\mathrm{CH}_{2} \mathrm{O}$ with $\mathrm{CH}_{4}$ (Table S1 in the Supplement) could simply be due to pho- 
tochemical $\mathrm{CH}_{2} \mathrm{O}$ formation of correlated primary species. The test simulation $(\mathrm{E} 9, \mathrm{IR}=0.18)$ shows a moderate impact of the assumed $\mathrm{CH}_{2} \mathrm{O}$ emission rate. However, $\mathrm{CH}_{2} \mathrm{O}$ is underpredicted by $50 \%$ (Table 3 ) in the base case simulation that includes the primary emissions.

A modification to the base case simulation was performed to check the impact of the assumed partitioning of oil/gas $\mathrm{NO}_{\mathrm{x}}$ emissions between $\mathrm{NO}, \mathrm{NO}_{2}$ and $\mathrm{HNO}_{2}$ by assuming all $\mathrm{NO}_{\mathrm{x}}$ emissions as $\mathrm{NO}$ only (E10 case in Table 4). The E10 case results ( $I R=0.23)$ are close to the $\mathrm{E} 9$ case $(\mathrm{IR}=0.18)$, suggesting a small $5 \%$ impact related to this assumption about $\mathrm{NO}_{\mathrm{x}}$ emission partitioning. This simulation also indicates the insignificant role of primary $\mathrm{HNO}_{2}$ emissions in simulating the high $\mathrm{O}_{3}$ episode at Horse Pool.

\subsubsection{Sensitivity to photochemical processes}

It is known that the major hydroxyl radical $(\mathrm{OH})$ production in urban photochemical smog comes from the reaction of atomic oxygen $\left(\mathrm{O}^{1} \mathrm{D}\right)$ with water vapor $\left(\mathrm{H}_{2} \mathrm{O}\right)$ molecules. Both $\mathrm{H}_{2} \mathrm{O}$ and $\mathrm{O}_{3}$ (the photolytic source of $\mathrm{O}^{1} \mathrm{D}$ ) are abundant in polluted urban air in summertime. We checked the importance of this pathway in $\mathrm{O}_{3}$ production in the $\mathrm{UB}$, by shutting off this reaction in the model. The results indicate that elimination of this pathway ( $\mathrm{C} 1$ in Table 4) in the model reduces $\mathrm{O}_{3}$ concentrations to some degree, with an IR for this case of 0.25 . The model therefore forms significant $\mathrm{O}_{3}$ through other radical-producing pathways.

Similarly, the model sensitivity to the radical formation channel from $\mathrm{CH}_{2} \mathrm{O}$ photolysis was determined by turning off this photolysis reaction (C2 in Table 4). This pathway has twice the impact of the case $\mathrm{C} 1$, illustrating the importance of primary and secondary $\mathrm{CH}_{2} \mathrm{O}$ as a radical source term within the calculations. Additional radical sources, primarily dicarbonyls and hydroxy ketones, are the remaining peroxy radical sources contributing to the high modeled $\mathrm{O}_{3}$. The radical production from photolysis of various carbonyls for the UBWOS-2013 are studied in detail by Edwards et al. (2014).

Another uncertainty is the loss of $\mathrm{NO}_{\mathrm{x}}$ species to particle surfaces. This process depends on aerosol surface area, humidity and other factors. Dinitrogen pentoxide $\left(\mathrm{N}_{2} \mathrm{O}_{5}\right)$ formed during the night can participate in heterogeneous aerosol reactions to form nitrate, effectively removing $\mathrm{NO}_{\mathrm{x}}$ from the system (Brown et al., 2006). The base case simulation does not include aerosols or any treatment of $\mathrm{N}_{2} \mathrm{O}_{5}$ conversion to nitrate. In order to estimate an upper limit for the impact of this process, we performed a test simulation in which the chemical reaction between nitrogen trioxide $\left(\mathrm{NO}_{3}\right)$ and $\mathrm{NO}_{2}$ is assumed to yield two $\mathrm{HNO}_{3}$ molecules directly, rather than through the $\mathrm{N}_{2} \mathrm{O}_{5}$ intermediate. The results for this case ( $\mathrm{C} 3$ in Table 4) show that the model could be somewhat $(I R=0.19)$ sensitive to the treatment of this heterogeneous pathway, but can still simulate high $\mathrm{O}_{3}$ concentrations under such upper limit assumptions. We note that adding this heterogeneous pathway reduces the positive bias in $\mathrm{NO}_{\mathrm{x}}$ seen in the top-down model case in Table 3 . For the time period of the sensitivity runs, the median of model to observation ratio (MMO) of $\mathrm{NO}_{\mathrm{y}}$ is 0.64 . By adding the heterogeneous pathway the MMO for $\mathrm{NO}_{\mathrm{x}}$ decreases from 1.06 to 0.88 , and the $\mathrm{MMO}$ for $\mathrm{HNO}_{3}$ increases from 0.23 to 0.41 , which is more consistent with the magnitude of the $2013 \mathrm{NO}_{\mathrm{y}}$ underprediction.

\section{Summary}

Our study using the fully coupled meteorology-chemistry WRF-Chem model provides a means of examining the different factors driving high $\mathrm{O}_{3}$ levels during the wintertime over the UB from a regional modeling perspective. Two highly contrasting wintertime periods simulate snow-free 2012 and snow-covered 2013. The simulations were performed with two different emission scenarios for $\mathrm{O}_{3}$ precursors from the oil/gas sector, the bottom-up EPA NEI-2011 (version 1) inventory and a top-down emission estimate based on observed ratios of VOCs and $\mathrm{NO}_{\mathrm{y}}$ to $\mathrm{CH}_{4}$ combined with the observed $\mathrm{CH}_{4}$ emission rate from Karion et al. (2013). The same meteorological options and domain configuration within the WRF-Chem model were used. They adequately simulate conditions during both 2012 and 2013 and, most importantly, the low wind speeds, low temperatures, and shallow mixing heights associated with cold pool episodes during the winter of 2013. The high-resolution 3-D model grid and tight coupling between meteorology and tracer transport in WRFChem enables a proper simulation of the pollutant accumulation in shallow mixed layers and their transport aloft over the UB.

Comparisons of results contrasting the 2012 and 2013 winter simulations show that model $\mathrm{O}_{3}$ is very insensitive to differences between the bottom-up and top-down scenarios during low $\mathrm{O}_{3}$ conditions in 2012, but highly sensitive to these differences during 2013, with only the top-down emission data set able to reproduce the observed high $\mathrm{O}_{3}$ events in 2013. Total oil/gas sector emissions of $\mathrm{NO}_{\mathrm{x}}$ are a factor 4 higher, and VOC emissions are $56 \%$ lower, in the bottomup inventory compared to the top-down emission data set in the UB. Statistics for $\mathrm{NO}_{\mathrm{x}}$ and VOC species are consistent for both years, showing that the bottom-up inventory yields a high bias in simulated $\mathrm{NO}_{\mathrm{y}}$ and nitrogen containing compounds and a low bias for several VOCs. Using the top-down emissions results in much better agreement with the observed precursor levels, though low biases in VOCs and $\mathrm{NO}_{\mathrm{y}}$ on the order of $10-30 \%$ are characteristic of the top-down simulations for both years. Under the snow-free conditions of 2012, the meteorological conditions led to effectively coupling air within the UB to air masses further upwind, making $\mathrm{O}_{3}$ levels less dependent on the local oil/gas sector emissions. In contrast, the cold pool conditions of 2013 confined locally emitted $\mathrm{NO}_{\mathrm{x}}$ and VOCs to very shallow (50-200 m) PBLs, mak- 
ing ground level $\mathrm{O}_{3}$ quite sensitive to the adopted emission estimates and products, particularly the $\mathrm{VOC} / \mathrm{NO}_{\mathrm{x}}$ emission ratio.

The $\mathrm{CH}_{4}$ emission estimate by Karion et al. (2013), which forms the basis of our top-down inventory, is based on a single flight in 2012, which only sampled $\mathrm{CH}_{4}$ emissions downwind of operations within the eastern part of the UB. Consistent with the $\mathrm{NO}_{\mathrm{x}}$ and $\mathrm{VOC}$ emissions, the top-down model results show a 10 and $40 \%$ low bias for monthly $\mathrm{CH}_{4}$ statistics in 2012 and 2013, respectively (Table 3). Assuming that meteorology is adequately represented in the model, one would conclude that the Karion et al. (2013) $\mathrm{CH}_{4}$ flux estimate of $55 \times 10^{3} \mathrm{~kg} \mathrm{~h}^{-1}( \pm 30 \%)$, when applied over the entire $\mathrm{UB}$, is a reasonable lower limit. Moreover, $\mathrm{NO}_{\mathrm{x}}$ and VOC low biases in the top-down emission case could be eliminated by simply increasing the $\mathrm{CH}_{4}$ basin-wide emission specification by $\sim 25 \%$. By way of contrast, the bottom-up inventory requires significantly larger modifications in order to eliminate $\mathrm{NO}_{\mathrm{y}}$ and VOC biases, suggesting a large uncertainty with the methods and numbers used to derive the oil/gas sector emissions found in the NEI-2011 inventory.

A number of perturbation cases to the base model simulation were performed for the 29 January-8 February 2013 high $\mathrm{O}_{3}$ episode in order to quantify the impact of various model settings, emission reduction scenarios, and photochemical pathways. The impact of meteorological settings applied within the WRF model is not addressed, and is left to future work. The largest $\mathrm{O}_{3}$ impacts are found to be associated with snow on the ground. Without a high surface albedo and reduced $\mathrm{O}_{3}$ deposition velocity induced by the snow cover, the model fails to reproduce the high daytime $\mathrm{O}_{3}$ observed at a surface site. The 3-D transport and photochemistry formulation afforded by the WRF-Chem model allows the relative importance of snow cover to $\mathrm{O}_{3}$ deposition to be calculated meaningfully, and this is found to be a necessary condition for the high $\mathrm{O}_{3}$ events.

The $\mathrm{NO}_{\mathrm{x}}$ and $\mathrm{VOC}$ emission reduction cases show that high $\mathrm{O}_{3}$ episodes in the UB are VOC limited. The impact of $\mathrm{NO}_{\mathrm{x}}$ reductions is found to be very nonlinear, with reductions showing significant $\mathrm{O}_{3}$ impacts only after the first $2 / 3$ of the specified oil/gas sector $\mathrm{NO}_{\mathrm{x}}$ emissions are removed. Our results suggest that efforts to reduce wintertime $\mathrm{O}_{3}$ from the oil/gas sector through VOC reductions would benefit the most by targeting the less abundant aromatic compounds, as their contribution to high $\mathrm{O}_{3}$ formation is nearly as significant as the alkanes that comprise the major fraction of the total VOC emissions in the UB. It should be noted that total VOC emissions, especially $\mathrm{VOC} / \mathrm{NO}_{\mathrm{x}}$ emission ratios over urban areas (e.g., Salt Lake City), are much lower than those in the UB; therefore, such urban areas are not expected to experience high wintertime ozone production when cold-pooltype wintertime conditions are present.

Similar to the finding of Edwards et al. (2014), our sensitivity analysis shows that it is important to quantify the primary and secondary sources of $\mathrm{CH}_{2} \mathrm{O}$ in the UB during wintertime. Despite the underprediction of $\mathrm{CH}_{2} \mathrm{O}$, its photolysis is a dominant source of ozone-producing radicals within the model. Another important conclusion from the sensitivity analysis is that high $\mathrm{O}_{3}$ concentrations can be simulated without direct emissions of $\mathrm{HNO}_{2}$, which was previously considered a potential radical source under snowy conditions.

Several future refinements may be necessary in order to better simulate the meteorological and photochemical processes pertinent to the wintertime conditions. Although using emissions based on observations offers significant improvement over the bottom-up emissions inventory, there are potentially important details missing in the top-down emission estimates. VOC speciation profiles for oil vs. NG wells, and other stationary sources, are known to be different (Warneke et al., 2014), and the treatment of $\mathrm{NO}_{\mathrm{x}}$ emissions in the topdown approach does not consider the heterogeneity of the various source categories. Thus, a synergy between bottomup and top-down approaches will be needed in order to develop more accurate emission inventories for the oil/gas sector in the UB. Further refinements in gas-phase chemical mechanisms may be needed to better characterize the conditions pertinent to oil/gas emissions in wintertime beyond the chemistry associated with summertime urban photochemistry.

The 3-D meteorology-chemistry model framework and top-down emission estimates presented here provide a unique set of tools and methods to help better understand and quantify the major factors determining high wintertime $\mathrm{O}_{3}$ levels within the Uinta Basin, UT, and in other oil and natural gas production regions with potentially similar conditions.

\section{The Supplement related to this article is available online at doi:10.5194/acp-15-411-2015-supplement.}

Acknowledgements. Part of this work (R. Ahmadov and S. McKeen) is supported by the US Weather Research Program within the NOAA/OAR Office of Weather and Air Quality. The authors thank David Parrish (NOAA and CU Boulder), Gail Tonnesen (EPA) and Seth Lyman (Utah State University) for useful discussions. We wish to thank Georg Grell and Steven Peckham (NOAA and CU Boulder) for the user support of the WRF-Chem model. We are grateful to two anonymous reviewers for their contributions to the improvements and clarifications of the manuscript. Measurements were funded in part by the Western Energy Alliance and NOAA's Climate and Health of the Atmosphere programs. The contents of this paper reflect only the opinions of the authors, and not necessarily those of National Oceanic and Atmospheric Administration, or any other individuals or organizations mentioned herein.

Edited by: J. H. Seinfeld 


\section{References}

Ahmadov, R., McKeen, S. A., Robinson, A. L., Bahreini, R., Middlebrook, A. M., de Gouw, J. A., Meagher, J., Hsie, E. Y., Edgerton, E., Shaw, S., and Trainer, M.: A volatility basis set model for summertime secondary organic aerosols over the eastern United States in 2006, J. Geophys. Res.-Atmos., 117, D06301, doi:10.1029/2011jd016831, 2012.

Alvarez, R. A., Pacala, S. W., Winebrake, J. J., Chameides, W. L., and Hamburg, S. P.: Greater focus needed on methane leakage from natural gas infrastructure, P. Natl. Acad. Sci. USA, 109, 6435-6440, doi:10.1073/pnas.1202407109, 2012.

Anenberg, S. C., Horowitz, L. W., Tong, D. Q., and West, J. J.: An estimate of the global burden of anthropogenic ozone and fine particulate matter on premature human mortality using atmospheric modeling, Environ. Health Persp., 118, 1189-1195, doi:10.1289/ehp.0901220, 2010.

Baker, K. R., Simon, H., and Kelly, J. T.: Challenges to modeling "Cold Pool" meteorology associated with high pollution episodes, Environ. Sci. Technol., 45, 7118-7119, doi:10.1021/es202705v, 2011.

Banta, R. and Cotton, W. R.: An analysis of the structure of local wind systems in a broad mountain basin, J. Appl. Meteorol., 20, 1255-1266, doi:10.1175/1520-0450(1981)020< 1255:aaotso> 2.0.co;2, 1981 .

Banta, R. M., Senff, C. J., Alvarez, R. J., Langford, A. O., Parrish, D. D., Trainer, M. K., Darby, L. S., Hardesty, R. M., Lambeth, B., Neuman, J. A., Angevine, W. M., Nielsen-Gammon, J., Sandberg, S. P., and White, A. B.: Dependence of daily peak $\mathrm{O}_{3}$ concentrations near Houston, Texas on environmental factors: wind speed, temperature, and boundary-layer depth, Atmos. Environ., 45, 162-173, doi:10.1016/j.atmosenv.2010.09.030, 2011.

Brandt, A. R., Heath, G. A., Kort, E. A., O’Sullivan, F., Pétron, G., Jordaan, S. M., Tans, P., Wilcox, J., Gopstein, A. M., Arent, D., Wofsy, S., Brown, N. J., Bradley, R., Stucky, G. D., Eardley, D., and Harriss, R.: Methane leaks from North American natural gas systems, Science, 343, 733-735, doi:10.1126/science.1247045, 2014

Brioude, J., Angevine, W. M., Ahmadov, R., Kim, S.-W., Evan, S., McKeen, S. A., Hsie, E.-Y., Frost, G. J., Neuman, J. A., Pollack, I. B., Peischl, J., Ryerson, T. B., Holloway, J., Brown, S. S., Nowak, J. B., Roberts, J. M., Wofsy, S. C., Santoni, G. W., Oda, T., and Trainer, M.: Top-down estimate of surface flux in the Los Angeles Basin using a mesoscale inverse modeling technique: assessing anthropogenic emissions of $\mathrm{CO}, \mathrm{NO}_{\mathrm{x}}$ and $\mathrm{CO}_{2}$ and their impacts, Atmos. Chem. Phys., 13, 3661-3677, doi:10.5194/acp13-3661-2013, 2013

Brown, S. S., Neuman, J. A., Ryerson, T. B., Trainer, M., Dube, W. P., Holloway, J. S., Warneke, C., de Gouw, J. A., Donnelly, S. G., Atlas, E., Matthew, B., Middlebrook, A. M., Peltier, R., Weber, R. J., Stohl, A., Meagher, J. F., Fehsenfeld, F. C., and Ravishankara, A. R.: Nocturnal odd-oxygen budget and its implications for ozone loss in the lower troposphere, Geophys. Res. Lett., 33, L08801, doi:10.1029/2006gl025900, 2006.

Carlton, A. G., Little, E., Moeller, M., Odoyo, S., and Shepson, P. B.: The Data Gap: can a lack of monitors obscure loss of clean air act benefits in fracking areas?, Environ. Sci. Technol., 48, 893894, doi:10.1021/es405672t, 2014.

Carter, W. P. L. and Seinfeld, J. H.: Winter ozone formation and VOC incremental reactivities in the Upper Green
River Basin of Wyoming, Atmos. Environ., 50, 255-266, doi:10.1016/j.atmosenv.2011.12.025, 2012.

Clements, C. B., Whiteman, C. D., and Horel, J. D.: Coldair-pool structure and evolution in a mountain basin: Peter Sinks, Utah, J. Appl. Meteorol., 42, 752-768, doi:10.1175/15200450(2003)042<0752:csaeia>2.0.co;2, 2003.

Cooper, O. R., Gao, R. S., Tarasick, D., Leblanc, T., and Sweeney, C.: Long-term ozone trends at rural ozone monitoring sites across the United States, 1990-2010, J. Geophys. Res.-Atmos., 117, D22307, doi:10.1029/2012jd018261, 2012.

de Gouw, J. A., Parrish, D. D., Frost, G. J., and Trainer, M.: Reduced emissions of $\mathrm{CO}_{2}, \mathrm{NO}_{\mathrm{x}}$, and $\mathrm{SO}_{2}$ from US power plants owing to switch from coal to natural gas with combined cycle technology, Earth's Future, 2, 75-82, doi:10.1002/2013ef000196, 2014

Dibb, J. E., Talbot, R. W., Munger, J. W., Jacob, D. J., and Fan, S. M.: Air-snow exchange of $\mathrm{HNO}_{3}$ and $\mathrm{NO}_{\mathrm{y}}$ at Summit, Greenland, J. Geophys. Res.-Atmos., 103, 3475-3486, doi:10.1029/97jd03132, 1998.

Edwards, P. M., Young, C. J., Aikin, K., deGouw, J., Dubé, W. P., Geiger, F., Gilman, J., Helmig, D., Holloway, J. S., Kercher, J., Lerner, B., Martin, R., McLaren, R., Parrish, D. D., Peischl, J., Roberts, J. M., Ryerson, T. B., Thornton, J., Warneke, C., Williams, E. J., and Brown, S. S.: Ozone photochemistry in an oil and natural gas extraction region during winter: simulations of a snow-free season in the Uintah Basin, Utah, Atmos. Chem. Phys., 13, 8955-8971, doi:10.5194/acp-13-8955-2013, 2013.

Edwards, P. M., Brown, S., Roberts, J., Ahmadov, R., Banta, R., de Gouw, J., Dubé, W., Field, R., Flynn, J., Gilman, J., Graus, M., Helmig, D., Koss, A., Langford, A., Lefer, B., Lerner, B., Li, R., Li, S., McKeen, S., Murphy, S., Parrish, D., Senff, C., Soltis, J., Stutz, J., Sweeney, C., Thompson, C., Trainer, M., Tsai, C., Veres, P., Washenfelder, R., Warneke, C., Wild, R., Young, C., Yuan, B., Zamora, R.: High winter ozone pollution from carbonyl photolysis in an oil and gas, Nature, 514, 351-354, 2014.

Erisman, J. W., Vanpul, A., and Wyers, P.: Parametrization of surface-resistance for the quantification of atmospheric deposition of acidifying pollutants and ozone, Atmos. Environ., 28, 2595-2607, 1994.

Gilman, J. B., Lerner, B. M., Kuster, W. C., and de Gouw, J. A.: Source signature of volatile organic compounds from oil and natural gas operations in northeastern Colorado, Environ. Sci. Technol., 47, 1297-1305, doi:10.1021/es304119a, 2013.

Grell, G. A., Peckham, S. E., Schmitz, R., McKeen, S. A., Frost, G., Skamarock, W. C., and Eder, B.: Fully coupled "online" chemistry within the WRF model, Atmos. Environ., 39, 6957-6975, doi:10.1016/j.atmosenv.2005.04.027, 2005.

Helmig, D., Thompson, C. R., Evans, J., Boylan, P., Hueber, J., and Park, J. H.: Highly elevated atmospheric levels of Volatile Organic Compounds in the Uintah Basin, Utah, Environ. Sci. Technol., 48, 4707-4715, doi:10.1021/es405046r, 2014.

Jackson, R. B., Down, A., Phillips, N. G., Ackley, R. C., Cook, C.W., Plata, D. L., and Zhao, K. G.: Natural gas pipeline leaks across Washington, DC, Environ. Sci. Technol., 48, 2051-2058, doi:10.1021/es404474x, 2014.

Jerrett, M., Burnett, R. T., Pope, C. A., Ito, K., Thurston, G., Krewski, D., Shi, Y. L., Calle, E., and Thun, M.: Long-term ozone exposure and mortality, New Engl. J. Med., 360, 10851095, doi:10.1056/NEJMoa0803894, 2009. 
Johansson, C. and Granat, L.: An experimental-study of the dry deposition of gaseous nitric acid to snow, Atmos. Environ., 20, 1165-1170, doi:10.1016/0004-6981(86)90150-2, 1986.

Karion, A., Sweeney, C., Pétron, G., Frost, G., Hardesty, R. M., Kofler, J., Miller, B. R., Newberger, T., Wolter, S., Banta, R., Brewer, A., Dlugokencky, E., Lang, P., Montzka, S. A., Schnell, R., Tans, P., Trainer, M., Zamora, R., and Conley, S.: Methane emissions estimate from airborne measurements over a western United States natural gas field, Geophys. Res. Lett., 40, 43934397, doi:10.1002/grl.50811, 2013.

Katzenstein, A. S., Doezema, L. A., Simpson, I. J., Balke, D. R., and Rowland, F. S.: Extensive regional atmospheric hydrocarbon pollution in the southwestern United States, P. Natl. Acad. Sci. USA, 100, 11975-11979, doi:10.1073/pnas.1635258100, 2003.

Kemball-Cook, S., Bar-Ilan, A., Grant, J., Parker, L., Jung, J. G., Santamaria, W., Mathews, J., and Yarwood, G.: Ozone impacts of natural gas development in the Haynesville Shale, Environ. Sci. Technol., 44, 9357-9363, doi:10.1021/es1021137, 2010.

Kim, S. W., Heckel, A., Frost, G. J., Richter, A., Gleason, J., Burrows, J. P., McKeen, S., Hsie, E. Y., Granier, C., and Trainer, M.: $\mathrm{NO}_{2}$ columns in the western United States observed from space and simulated by a regional chemistry model and their implications for $\mathrm{NO}_{\mathrm{x}}$ emissions, J. Geophys. Res.-Atmos., 114, D11301, doi:10.1029/2008jd011343, 2009.

Kim, S.-W., McKeen, S. A., Frost, G. J., Lee, S.-H., Trainer, M., Richter, A., Angevine, W. M., Atlas, E., Bianco, L., Boersma, K. F., Brioude, J., Burrows, J. P., de Gouw, J., Fried, A., Gleason, J., Hilboll, A., Mellqvist, J., Peischl, J., Richter, D., Rivera, C., Ryerson, T., te Lintel Hekkert, S., Walega, J., Warneke, C., Weibring, P., and Williams, E.: Evaluations of $\mathrm{NO}_{\mathrm{x}}$ and highly reactive VOC emission inventories in Texas and their implications for ozone plume simulations during the Texas Air Quality Study 2006, Atmos. Chem. Phys., 11, 11361-11386, doi:10.5194/acp11-11361-2011, 2011.

Lareau, N. P., Crosman, E., Whiteman, C. D., Horel, J. D., Hoch, S. W., Brown, W. O. J., and Horst, T. W.: The persistent cold-air pool study, B. Am. Meteorol. Soc., 94, 51-63, doi:10.1175/bamsd-11-00255.1, 2013.

Lelieveld, J. and Dentener, F. J.: What controls tropospheric ozone?, J. Geophys. Res.-Atmos., 105, 3531-3551, doi:10.1029/1999jd901011, 2000.

Madronich, S.: Photodissociation in the atmosphere, 1. Actinic flux and the effects of ground reflections and clouds, J. Geophys. Res.-Atmos., 92, 9740-9752, doi:10.1029/JD092iD08p09740, 1987.

McKeen, S. A., Wotawa, G., Parrish, D. D., Holloway, J. S., Buhr, M. P., Hübler, G., Fehsenfeld, F. C., and Meagher, J. F.: Ozone production from Canadian wildfires during June and July of 1995, J. Geophys. Res., 107, doi:10.1029/2001JD000697, 2002.

Miller, S. M., Wofsy, S. C., Michalak, A. M., Kort, E. A., Andrews, A. E., Biraud, S. C., Dlugokencky, E. J., Eluszkiewicz, J., Fischer, M. L., Janssens-Maenhout, G., Miller, B. R., Miller, J. B., Montzka, S. A., Nehrkorn, T., and Sweeney, C.: Anthropogenic emissions of methane in the United States, P. Natl. Acad. Sci. USA, 110, 20018-20022, doi:10.1073/pnas.1314392110, 2013.

Neemann, E. M., Crosman, E. T., Horel, J. D., and Avey, L.: Simulations of a cold-air pool associated with elevated wintertime ozone in the Uintah Basin, Utah, Atmos. Chem. Phys. Discuss., 14, 15953-16000, doi:10.5194/acpd-14-15953-2014, 2014.
Oltmans, S. J., Schnell, R. C., Johnson, B. J., Pétron, G., Mefford, T., and Neely III, R.: Anatomy of wintertime ozone production associated with oil and gas extraction activity in Wyoming and Utah, Elem. Sci. Anth., 2, 000024, doi:10.12952/journal.elementa.000024, 2014a.

Oltmans, S. J., Karion, A., Schnell, R. C., Pétron, G., Sweeney, C., Wolter, S., Neff, D., Montzka, S. A., Miller, B. R., Helmig, D., Johnson, B. J., and Hueber, J.: A high ozone episode in winter 2013 in the Uinta Basin oil and gas region characterized by aircraft measurements, Atmos. Chem. Phys. Discuss., 14, 20117 20157, doi:10.5194/acpd-14-20117-2014, 2014b.

Pétron, G., Frost, G., Miller, B. R., Hirsch, A. I., Montzka, S. A., Karion, A., Trainer, M., Sweeney, C., Andrews, A. E., Miller, L., Kofler, J., Bar-Ilan, A., Dlugokencky, E. J., Patrick, L., Moore, C. T., Ryerson, T. B., Siso, C., Kolodzey, W., Lang, P. M., Conway, T., Novelli, P., Masarie, K., Hall, B., Guenther, D., Kitzis, D., Miller, J., Welsh, D., Wolfe, D., Neff, W., and Tans, P.: Hydrocarbon emissions characterization in the Colorado Front Range: a pilot study, J. Geophys. Res.-Atmos., 117, D04304, doi:10.1029/2011jd016360, 2012.

Pétron, G., Karion, A., Sweeney, C., Miller, B., Montzka, S., Frost, G., Trainer, M., Tans, P., Andrews, A., Kofler, J., Helmig, D., Guenther, D., Dlugokencky, E., Lang, P., Newberger, T., Wolter, S., Hall, B., Novelli, P., Brewer, A., Conley, S., Hardesty, M., Banta, R., White, A., Noone, D., Wolfe, D., and Schnell, R.: A new look at methane and nonmethane hydrocarbon emissions from oil and natural gas operations in the Colorado DenverJulesburg Basin, J. Geophys. Res.-Atmos., 119, 6836-6852, doi:10.1002/2013JD021272, 2014.

Rappenglück, B., Ackermann, L., Alvarez, S., Golovko, J., Buhr, M., Field, R. A., Soltis, J., Montague, D. C., Hauze, B., Adamson, S., Risch, D., Wilkerson, G., Bush, D., Stoeckenius, T., and Keslar, C.: Strong wintertime ozone events in the Upper Green River basin, Wyoming, Atmos. Chem. Phys., 14, 4909-4934, doi:10.5194/acp-14-4909-2014, 2014.

Reeves, H. D. and Stensrud, D. J.: Synoptic-scale flow and valley cold pool evolution in the western United States, Weather Forecast., 24, 1625-1643, doi:10.1175/2009waf2222234.1, 2009.

Rodriguez, M. A., Barna, M. G., and Moore, T.: Regional impacts of oil and gas development on ozone formation in the western United States, J. Air Waste Manage., 59, 1111-1118, doi:10.3155/1047-3289.59.9.1111, 2009.

Roy, A. A., Adams, P. J., and Robinson, A. L.: Air pollutant emissions from the development, production, and processing of Marcellus Shale natural gas, J. Air Waste Manage., 64, 19-37, doi:10.1080/10962247.2013.826151, 2014.

Ryerson, T. B., Trainer, M., Angevine, W. M., Brock, C. A., Dissly, R. W., Fehsenfeld, F. C., Frost, G. J., Goldan, P. D., Holloway, J. S., Hübler, G., Jakoubek, R. O., Kuster, W. C., Neuman, J. A., Nicks, D. K., Jr., Parrish, D. D., Roberts, J. M., Sueper, D. T., Atlas, E. L., Donnelly, S. G., Flocke, F., Fried, A., Potter, W. T., Schauffler, S., Stroud, V., Weinheimer, A. J., Wert, B. P., Wiedinmyer, C., Alvarez, R. J., Banta, R. M., Darby, L. S., and Senff, C. J.: Effect of petrochemical industrial emissions of reactive alkenes and $\mathrm{NO}_{\mathrm{x}}$ on tropospheric ozone formation in Houston, Texas, J. Geophys. Res., 108, 4249, doi:10.1029/2002JD003070, 2003.

Schnell, R. C., Oltmans, S. J., Neely, R. R., Endres, M. S., Molenar, J. V., and White, A. B.: Rapid photochemical production of 
ozone at high concentrations in a rural site during winter, Nat. Geosci., 2, 120-122, doi:10.1038/ngeo415, 2009.

Simon, H., Beck, L., Bhave, P. V., Divita, F., Hsu, Y., Luecken, D., Mobley, J. D., Pouliot, G.A., Reff, A., Sarwar, G., and Strum, M.: The development and uses of EPA's SPECIATE database, Atmos. Pollut. Res., 1, 196-206, doi:10.5094/apr.2010.026, 2010.

Stockwell, W. R., Kirchner, F., Kuhn, M., and Seefeld, S.: A new mechanism for regional atmospheric chemistry modeling, J. Geophys. Res.-Atmos., 102, 25847-25879, 1997.

Trainer, M., Parrish, D. D., Goldan, P. D., Roberts, J., and Fehsenfeld, F. C.: Review of observation-based analysis of the regional factors influencing ozone concentrations, Atmos. Environ., 34, 2045-2061, 2000.
Warneke, C., Geiger, F., Edwards, P. M., Dube, W., Pétron, G., Kofler, J., Zahn, A., Brown, S. S., Graus, M., Gilman, J. B., Lerner, B. M., Peischl, J., Ryerson, T. B., de Gouw, J. A., and Roberts, J. M.: Volatile organic compound emissions from the oil and natural gas industry in the Uintah Basin, Utah: oil and gas well pad emissions compared to ambient air composition, Atmos. Chem. Phys., 14, 10977-10988, doi:10.5194/acp14-10977-2014, 2014.

Zhong, S. Y., Whiteman, C. D., Bian, X. D., Shaw, W. J., and Hubbe, J. M.: Meterological processes affecting the evolution of a wintertime cold air pool in the Columbia Basin, Mon. Weather Rev., 129, 2600-2613, doi:10.1175/15200493(2001)129<2600:mpateo> 2.0.co;2, 2001. 